2021 المجلد (4)، العدد (6): 30 ديجله الإسوم

ص: 58 - 50

\title{
Jurisprudential characterization of the person infected with the Corona epidemic and the jurisprudential rulings resulting from his disposal in financial compensation contracts: Sale contract as a model
}

\author{
Mohamed Atia Saleh \\ College of Science and Arts in Dhahran Al-Janoub || King Khalid University || KSA
}

\begin{abstract}
This research aims to clarify the jurisprudential characterization of the person infected with the Corona epidemic, and to clarify the jurisprudential provisions resulting from his disposal in the sales contract; This is because the patient may suffer from obsessions that affect his behavior, and the researcher has combined the inductive approach by following the issues related to the topic of research, collecting and categorizing them, and the descriptive approach in terms of mentioning the sayings of the jurists in each issue with its evidence, with mentioning the sayings of the considered schools of jurisprudence, and the discussions on them as possible, and clarifying The most correct, and the reason for the weightingThe researcher came out with results, the most important of which are: The Corona epidemic can be described by what is called jurisprudence as a dreaded disease, selling the person infected with the Corona epidemic if he is not indeb ted to a foreigner or buying it from him for the same price is valid without the heirs' permission, whether debtor or not, and it is also true if it is a favoritism of one third or less Pre-emption is established for the partner in the case of the patient selling to an heir or someone else if the sale is made at the same price, pre-emption is established for the intercessor if the purchaser is from the patient by favoritism and the intercessor is foreign, and the option of the condition and the fault of the person suffering from the epidemic is not lost if there is an excuse such as loss of consciousness or the like.
\end{abstract}

Keywords: Corona epidemic - selling - favoritism - pre-emption - the option of the condition - the option of defect.

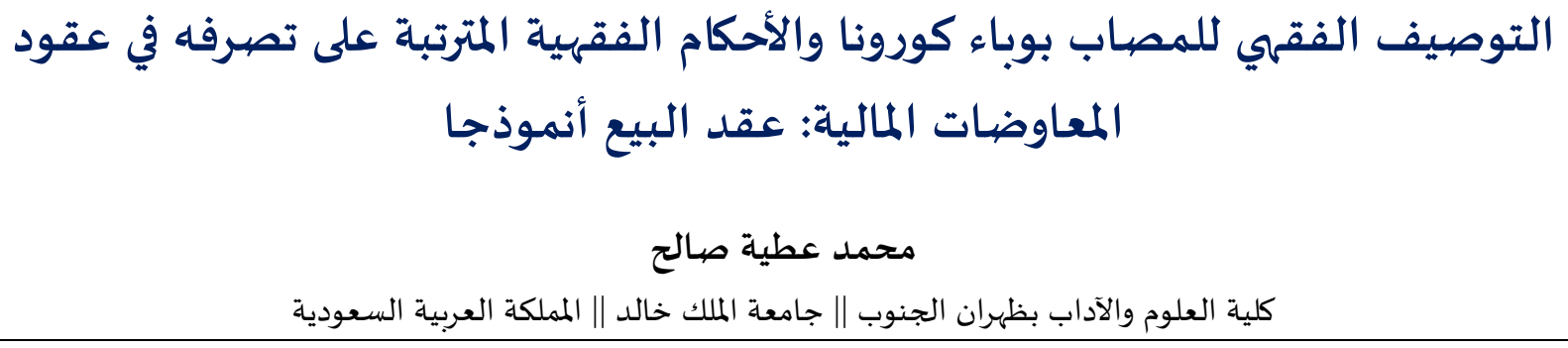

المستخلص: هدف هذا البحث إلى بيان التوصيف الفقهي للمصاب بوباء كورونا، وبيان الأحكام الفقهية المترتبة على تصرفه في عقد البيع؛ وذلك لما قد يعتري المصاب من وساوس تؤثر على تصرفاته، وقد جمع الباحث بين المنهج الاستقرائي بتتبع المسائل المتعلقة بئة بموضوع البحث وجمعها وتصنيفها والمنهج الوصفي من حيث ذكر أقوال الفقهاء في كل مسألة بأدلتها، مع ذكر أقوال المذاهب الفقهية

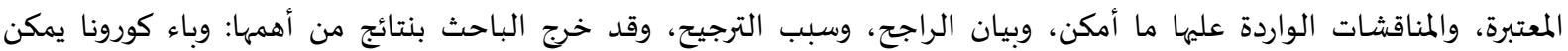

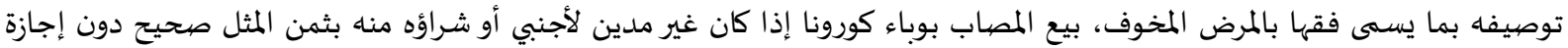

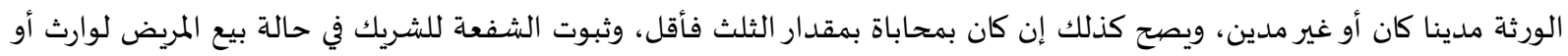

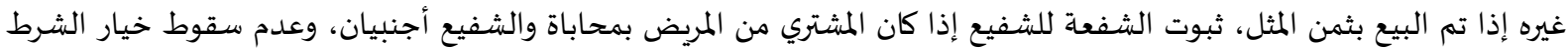

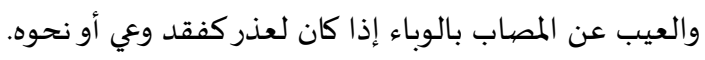


الحمد الله الرب الكريم، العليم الحكيم، أنزل الكتاب، وأرشـد العباد لصلاح الدنيا والمعاد، القائل في محكم

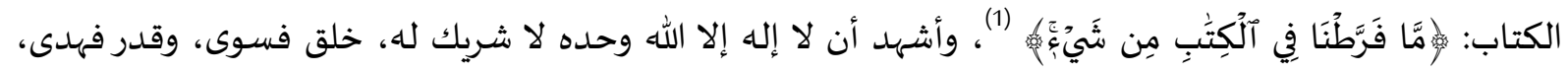
وشرع فأحكم، وأشهد أن محمدا عبده ورسوله، أمينه على وحياه، وصفوته من خلقهاه، صلى الله عليه وآله وصحباه وسلم تسليما كثيرا.

أما بعد: فقد انتشر في الآونة الأخيرة وباء من أخطر الأوبئة التي مر بها العالم على مر العصيور، أثر تأثيرا

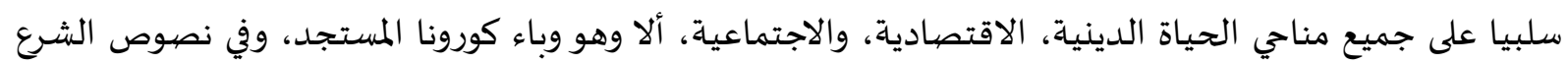

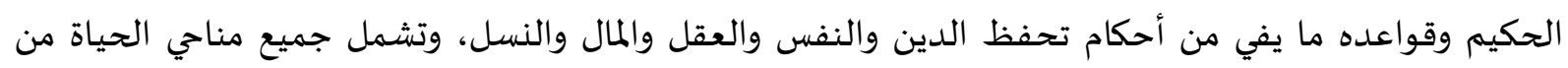

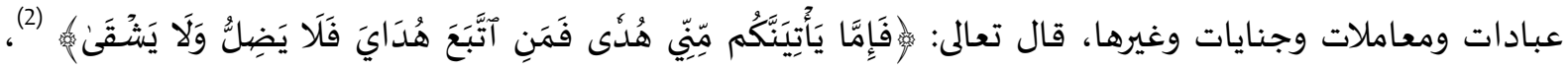

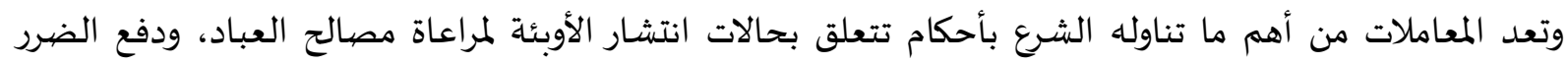

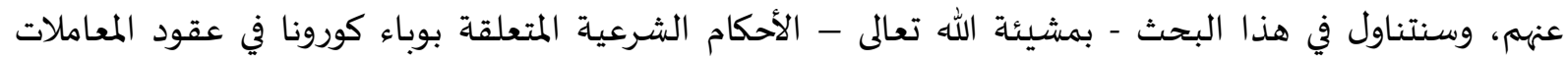
المالية (عقد البيع أنموذجا).

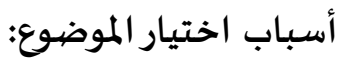

تظهر أسباب اختياري هذا الموضوع في النقاط الآتية: 1- حاجة المسلم الملحة للتعرف على ما يتعلق بجائحة كورونا من أحكام شرعية؛ خاصية ما ما يتعلق منها بجانب

$$
\text { الحلال والحرام. }
$$

2- جمع الأحكام الفقهية المتعلقة بوباء كورونا في عقد البيع في بحث مستقل يستطيع من يحتاج إلها الوصول

$$
\text { لجميعها بسهولة. }
$$

3- لم أقف على بحث جمعها موضحا فيها كلام الفقهاء، مرجحا بيهها بالأدلة الواضحة الشافية من الكتاب

$$
\text { والسنة، وغيرهما من الأدلة الشرعية. }
$$

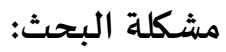

تكمن مشكلة هذا البحث في كونه يتعلق بعقد من أهم عقود المعاوضات المالية وأكثرها انتشارا بين الناس

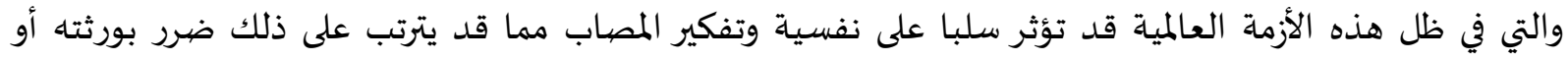

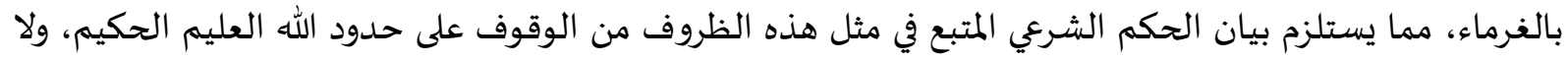

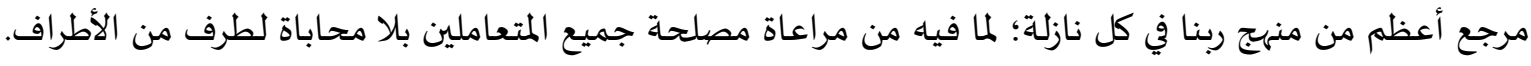

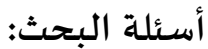

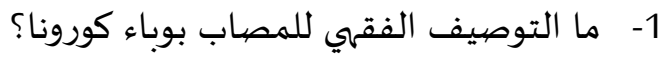
2- 2 - ما حكم بيع المصاب بالوباء للأجنبي؟ بوصباء

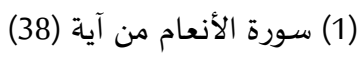

(2) سورة طه من آية (123) سن الة (3) 


$$
\text { 3- ما حكم بيع المصاب بالوباء للوارث؟ }
$$

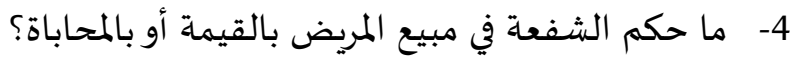

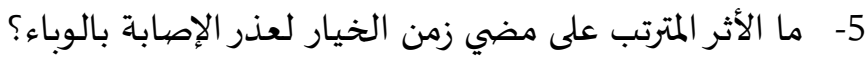

يهدف البحث في هذا الموضوع إلى ما يلي:

1- جمع الأحكام الفقهية المتعلقة بكورونا في عقد البيع في بحث مستقل يستطيع من يحتاج إلها التعرف على يلى

$$
\text { جميعها بيسر وسهولة. }
$$

2- بيان الأحكام الشرعية المتعلقة بوباء كورونا في عقد البيع.

3- الربط بين المقصد الشرعي والحكم في بعض مسائل البحث؛ لبيان عظمة التشريع الإسلامي، خاصة وأن هذا

من أسباب زيادة إيمان المكلف وقناعته بالحكم الشرعي. 4- بيان صلاحية وشمولية هذا الدين وصلاحيته لكل زمان ومكان.

$$
\text { تكمن أهمية بحث هذا الموضوع فيما يلي: }
$$

أهمية الموضوع:

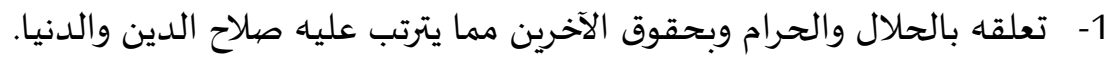

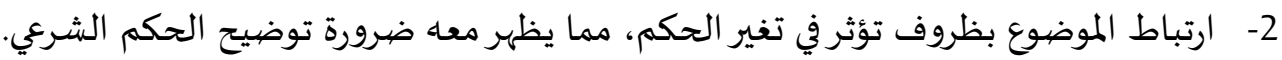

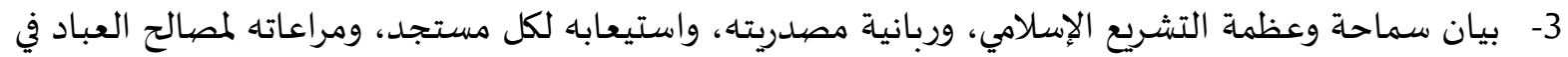

$$
\text { جميع الظروف والأحوال. }
$$

منهرج البحث:

سوف يسلك الباحث - بمشيئة الله تعالى- في هذا البحث المنهج الاستقرائي، حيث يستقرئ المسائل المتعلقة بالموضوع من كتب الفقه، ويقوم بجمعها، وتصنيفها، ثم يتبع المنهج الوصفي في بيان أقوال الفقهاء في حكم تلك لك

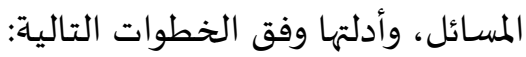
1- إذا كانت المسألة من مواضع الاتفاق فاذكر حكمها بدليلها، مع توثيق الاتفاق من المراجع المعتبرة.

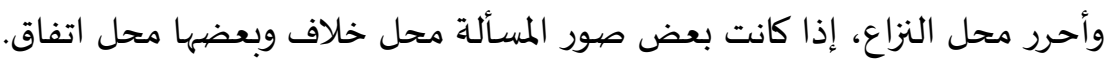

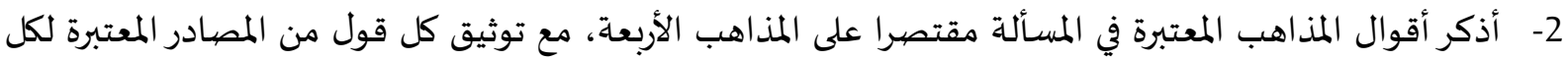
مذهب إن تيسر، وإن تعذروجود نص في المسألة لمذهب سلكت في ذلك مسلك التخريج، وترتيب المذاهب في في كل

$$
\text { قولٍ حسب التأريخ الزمني. }
$$

3- عرض أدلة الأقوال، مع بيان وجاه الدلالة، وتوثيقه إن أمكن أو الاجتهاد في استنباط وجه الدلالة بعد استفراغ

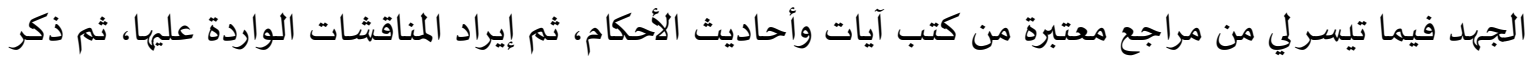

$$
\text { 4- عزو الآيات القرآنية الواردة في البحث مع كتابتها بالرسم العثماني. }
$$

5- تخريج الأحاديث الواردة في البحث مع ذكر درجة الحديث إن لم يكن في الصحيحين معتمدا على الكتب المعتمدة 
الدراسـات السـابقة:

لم يتعرض أحد من الفقهاء القدامى للكتابة بشكل مستقل للأحكام المتعلقة بالأوبئة عموما، وإنما قد يوجد

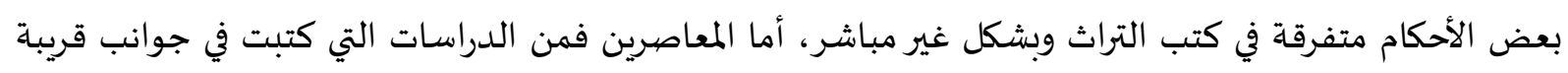
من هذا الموضوع وتيسرلي الاطلاع منها على ما يلي: 1- الأحكام الشرعية المتعلقة بالوباء والطاعون مع دراسة فقهية للأحكام الشرعية المتعلقة بفيروس كورونا لأبي الأبي

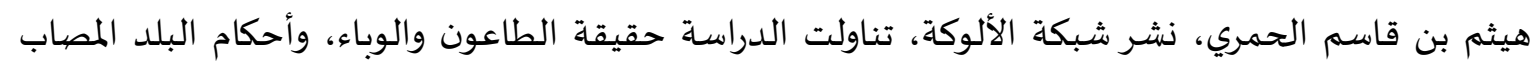

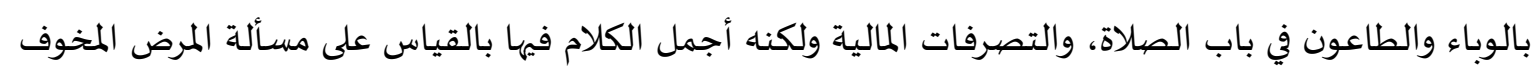

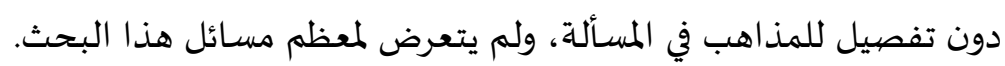

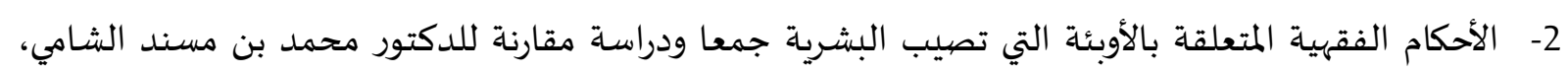
كلية الشريعة، الجامعة الإسلامية بالمدينة المنورة.

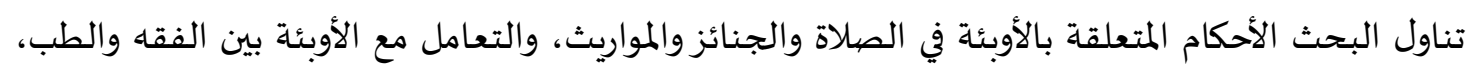
ولم يتعرض للأحكام المتعلقة بالأوبئة في عقود المعاوضات المعات المالية.

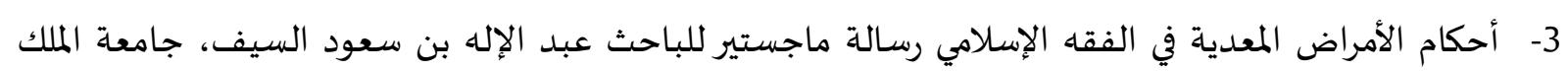

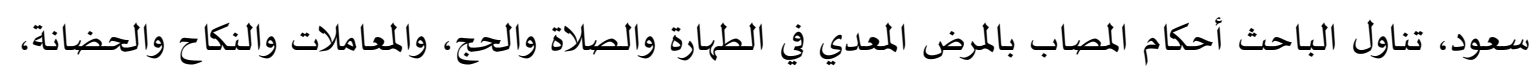
والجنايات، وأحكام المخالط للمصاب بالمرض المعدي، ولم يتطرق البحث لألمكام عقد المباب البيع.

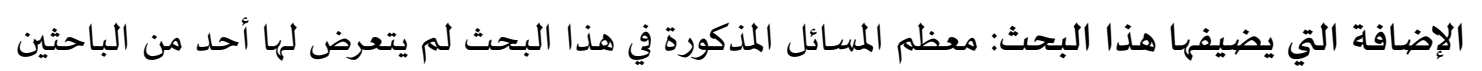

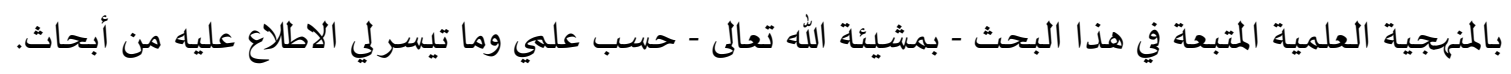
حدود البحث: نطاق البحث وحدوده يتضمن التوصيف الفقهي للمصاب بوباء كورونا المستجد، والأحكام الفقهية المتترتبة على تصرف في عقد البيع.

خطة البحث: ينقسم هذا البحث إلى مقدمة وخمسـة مباحث وخاتمة:

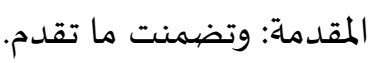

المبحث الأول: التعريف بأهم المفاهيم والتوصيف الفقهي للمصاب بفيروس كورونا

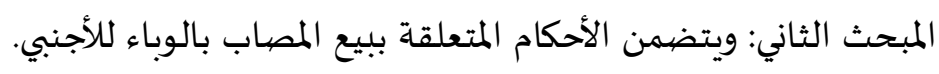
المبحث الثالث: حكم بيع المصاب لوارثه.

المبحث الرابع: حكم الشفعة في مبيع المريض بالقيمة أو بالمحاباة.

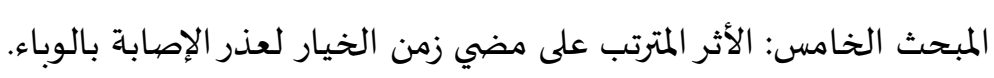
الخاتمة: وفيها النتائج والتوصيات. 
المبحث الأول: التعريف بأهم المفاهيم والتوصيف الفقهي للمصياب بفيروس كورونا

المطلب الأول: أهم المفاهيم والمصطلحات المتعلقة بموضوع البحث: - أولا: تعريف الوباء لغة: مادة وبأ: الوبأ مهموز: الطّاعون، وهو أيضياً كلّ مَرَض عامّة، تقول: أصهاب أهل الكورة

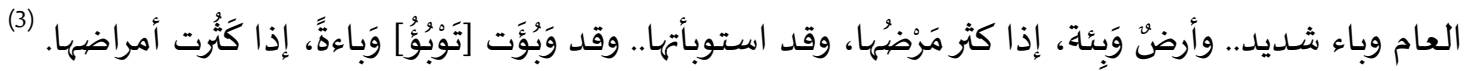

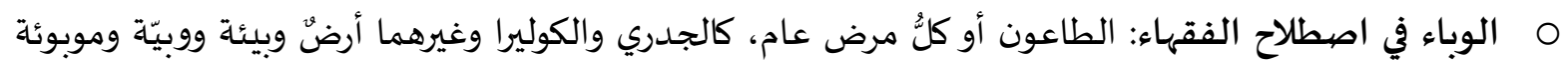
إذا كثر مرضها.

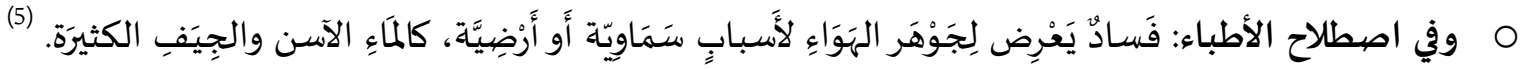
- انيا: تعريف عقود المعاوضات المالية: المعاوضات المالية مركب اضافي من عدة ألفاظ نعرف كلا منها على حده:

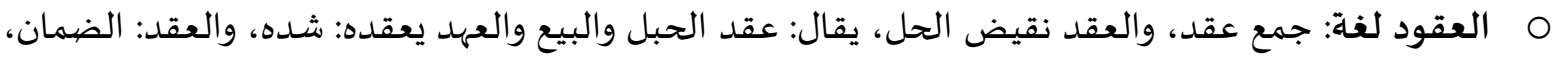
والعهد. (6)

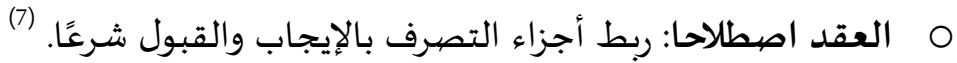

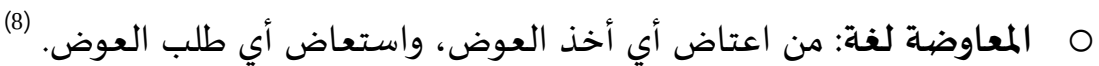

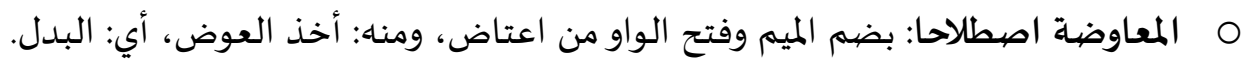

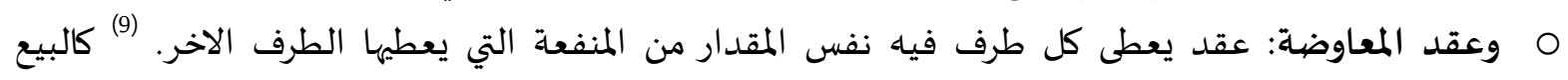
والإجارة والاستصناع وغيرها. O المال لغة: ما ملكته من جميع الأشياء. (10)

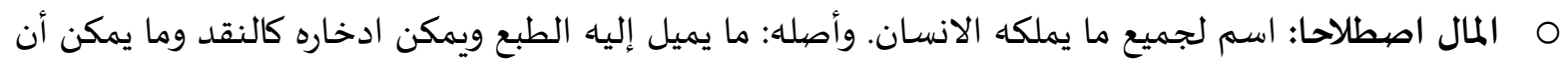

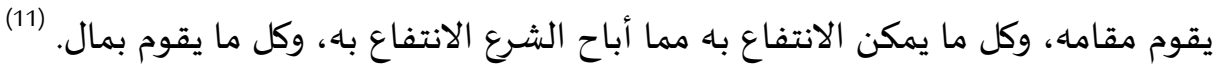

O لغة: البيع: ضيد الشراء، والبيع: الشراء أيضا، وهو من الأضيداد. وبعت الشيءء: شريته. (12)

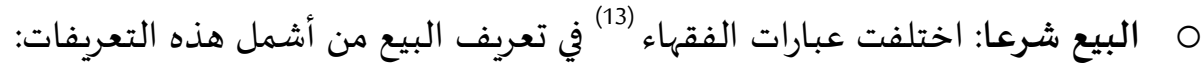

(3) الفراهيدي: العين 418/8، باب الباء، مادة وبأ.

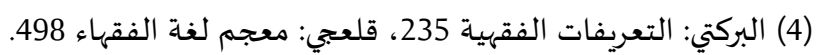

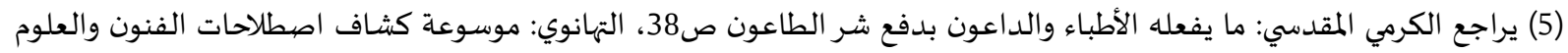

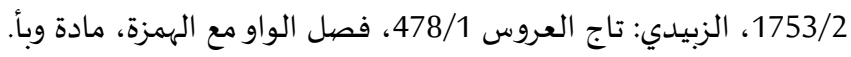

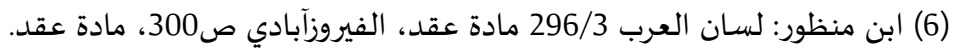

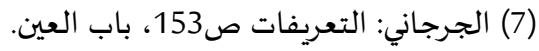

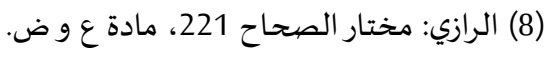

(9) قلعجي: معجم لغة الفقهاء 438.

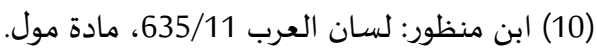
(11) قلعجي: معجم لغة الفقهاء 397.

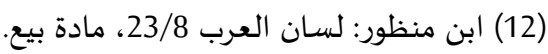
(13) عند الحنفية: مبادلة المال بالمال بالتراضي. الزيلعي: تبيين الحقائق شرح كنز الدقائق 2/4، الزبيدي: الجوهرة النيرة 285/1، وقال

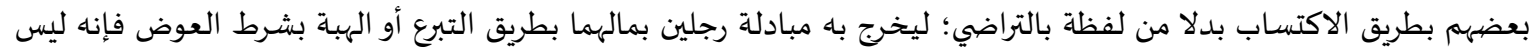

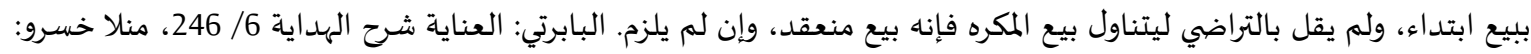


O مو مبادلة عين أو منفعة مباحة مطلقا بأحدهما كذلك على التأييد فيهما، بغير ربا ولا قرض). (14)

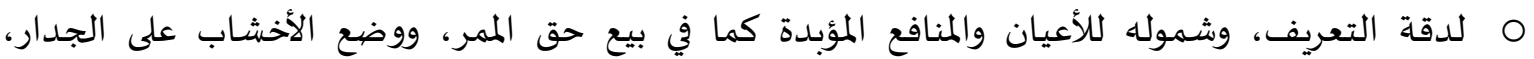

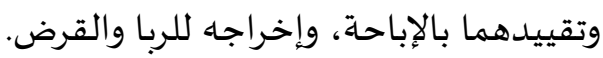

المطلب الثاني: التوصيف الفقهي للمصاب بفيروس كورونا يتضمن هذا المطلب بعض الحقائق العلمية حول فيروس كورونا المستجد والتي من أهمها المسميات والأعراض الشائعة لهذا الوباء، وتعريف مرض الموت عند الفقهاء؛ لنستطيع من خلال إسقاط هذه الحقائق العلمية على التعريف الفقهي أن نحدد التوصيف الفقهي للإصابة بهذا الوباء، وينقسم هذا المطلب إلى فرئي فرعين:

الفرع الأول: بعض الحقائق العلمية المتعلقة بفيروس كورونا المستجد:

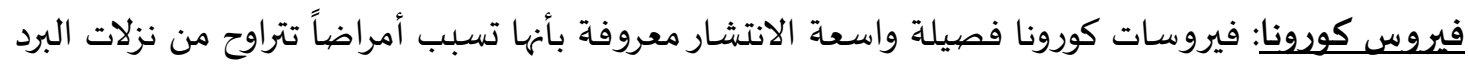
الشائعة إلى الاعتلالات الأشـد وطأة مثل متلازمة الشرق الأوسط التنفسية (MERS) ) ومتلازمة الالتهاب الرئوي الحاد معاد

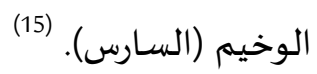

مرض كوفيد-19: هو مرض معد يسببه آخر فيروس تم اكتشافه من سلالة فيروسات كورونا. ولم يكن هناك أي علم بوجود هذا الفيروس الجديد ومرضاه قبل بدء تفشيه في مدينة ووهان الصينية في كانون الأول/ ديسمبر 2019.

فيروس كورونا المستجدي: يتمثل فيروس كورونا الجديد في سلالة جديدة من فيروس كورونا لم تُكشف إصابة البشر بها سابقاً.

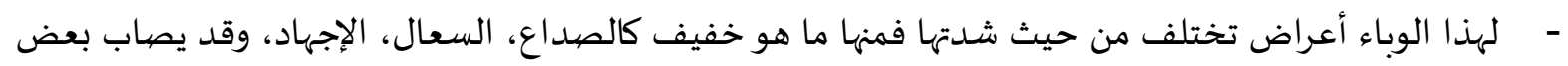

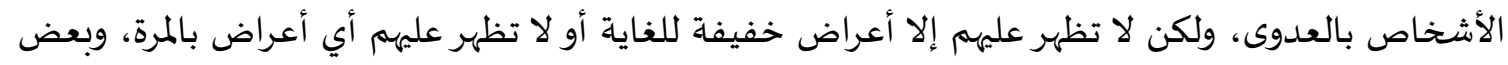

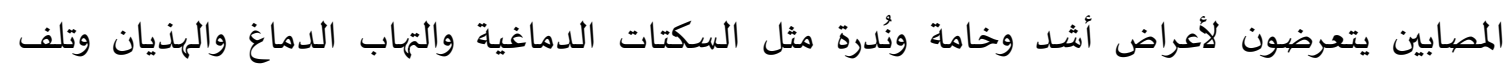

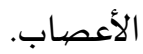
- يتعافى من المرض معظم الأشخاص (نحو 80\%) الذين تظهر عليهم الأعراض دون الحاجة إلى العلاج في

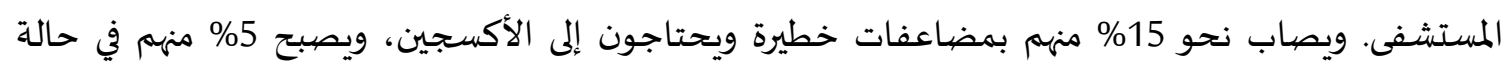
حرجة ويحتاجون إلى العناية المركزة.

درر الحكام شرح غرر الأحكام 142/2، والصحيح أن قيد التراضي لابد منه؛ فإنه لا يفهم البيع إلا إذا كانت المبادلة بالتراضي، وأن

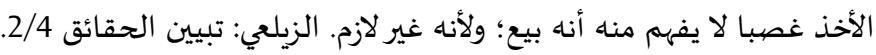

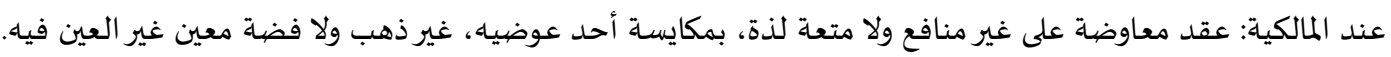

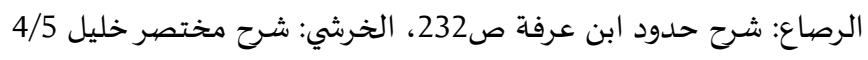

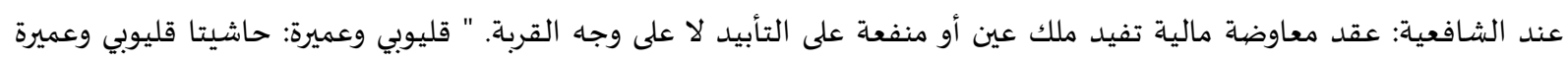

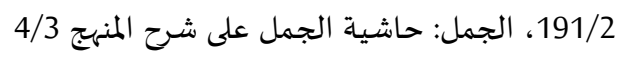

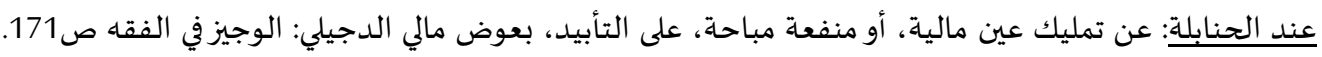

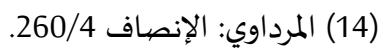
(15) موقع منظمة الصحة العالمية، مرض فيروس كورونا) كوفيد19) : سؤال وجواب المراب https://www. who. int/ar/emergencies/diseases/novel-coronavirus-2019/advice-for-public/q-a-coronaviruses (16) نفس المرجع السابق. 
- ل الوجد علاج محدد للمرض الذي يسببه فيروس كورونا المستجد. غير أن العديد من أعراضها يمكن معالجتها،

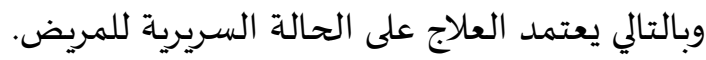

- قد يصاب أي شخص بعدوى كوفيد-19، ويعاني من مضاعفات خطيرة أو يتوفى في أي عمر كان. (17) - وفيات وباء كورونا تجاوزت أربعة مليون وفاة حتى الآن (18) -

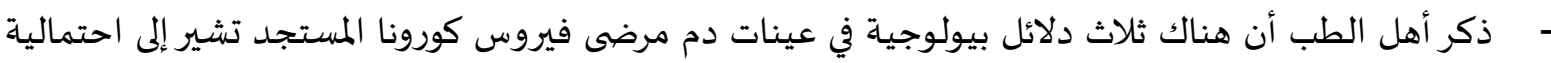
وفاة المصاب بالفيروس بنسبة تصل إلى 90\% وذلك قبل الوفاة بنحو عشرة أيام، وذلك وفقاً لصحيفة دئل ديلي

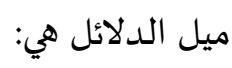

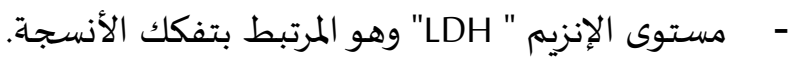
- - مستوى "C-CRP" وهو بروتين يتم إنتاجه أثناء الالتهاب. - انخفاض نوع من خلايا الدم البيضاء الموجودة في الدم تسمى "الخلايا الليمفاوية". وأكد الباحثون الذين نشروا دراستهم في مجلة "Nature Machine Intelligence" أنه يمكن قياس الدياء الدلائل الثلاث بسهولة في أي مستشفى. (19) الفرع الثاني: تعرف مرض الموت عند الفقهاء:

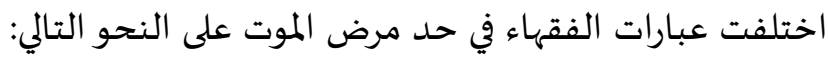
عند الحنفية: هو ما يتصل باء الموت. (20)

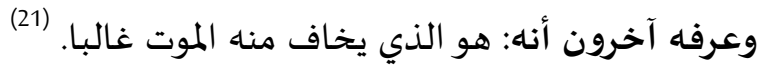

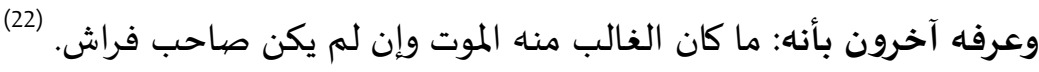

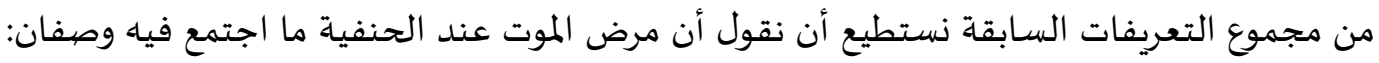
1- - 1 - أن يكون مرضا مخوفا يغلب فيه الموت.

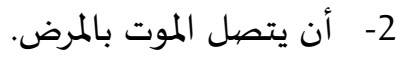

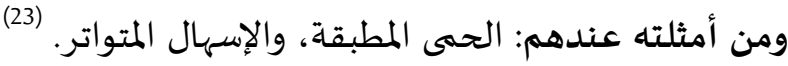

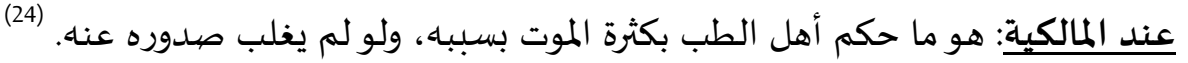

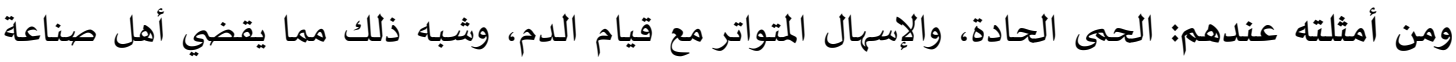
الطب بأن الهلاك بسبباه كثير. (25)

(17) (17) نفس المرجع السابق.

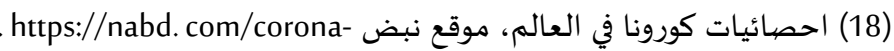
(19) نشر عنوان بمقال في موقع الحرة تحت عنوان قبل ساعة الصفر ب10 أيام 3 أعراض تشير إلى احتمالية وفاة مريض كورونا بنسبة

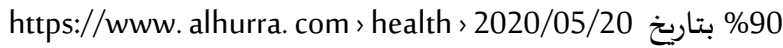

(20) (السرخسي: المبسوط 157/6.

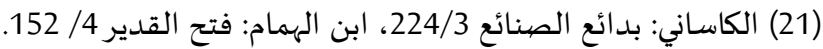
(22) ابن عابدين: رد المحتار على الدر المختار 661/6، البلخي: الفتاوى الهندية البنائ 176/4، وفيه (أنه المختار للفتوى)

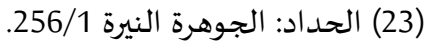

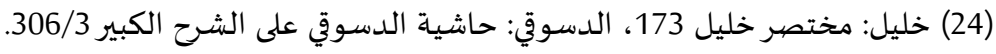

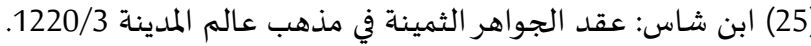




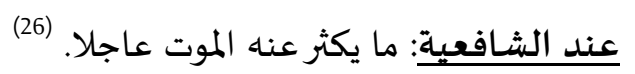

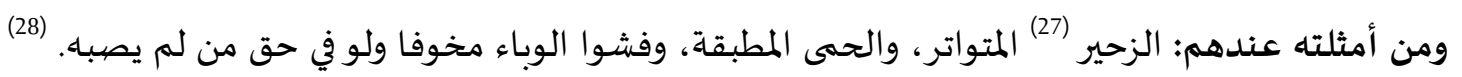

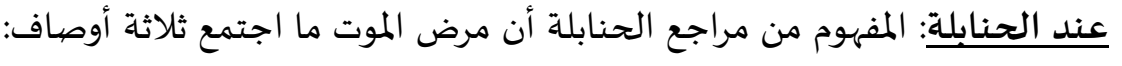

$$
\begin{aligned}
& \text { 1- امتداد المرض ومصياحباء الفراش. } \\
& \text { 2- حصول الموت منه. } \\
& \text { 3- قول عدلان من أهل الطب أنه مخوف. (29) }
\end{aligned}
$$

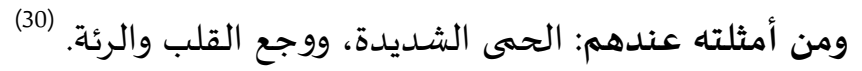

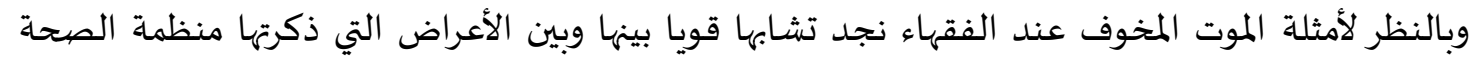

العالمية لأعراض وباء فيروس كورونا المستجدل

التعريف المختار: من خلال ما تم عرضها من التعريفات السابقة يظهر لي - والله أعلم - أن أولى التعريفات

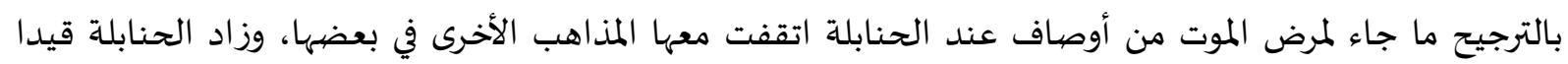

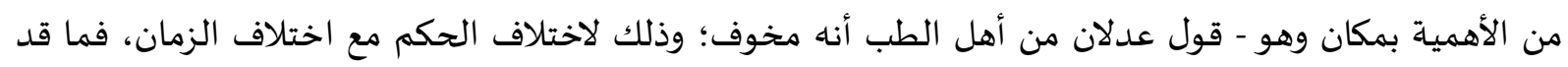

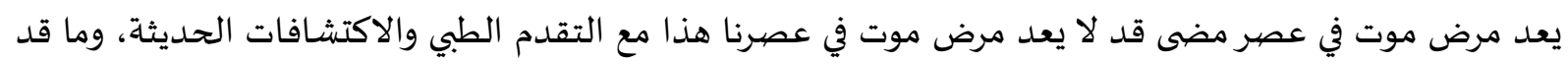

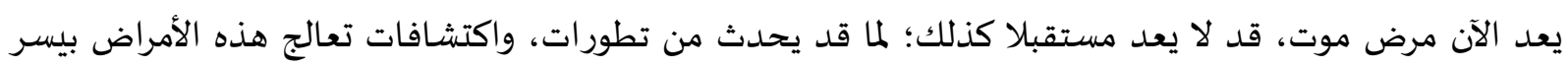

من خلال ما تم ذكره من حقائق علمية عن الوباء وما ذكره الفقهاء في تعريف مرض الموت نستطيع أن

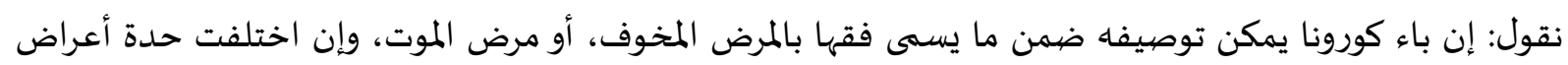

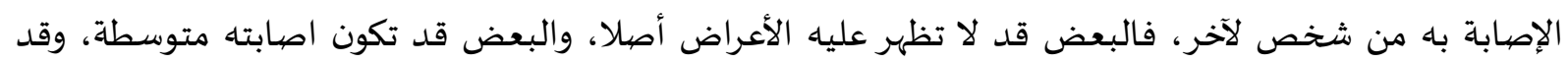

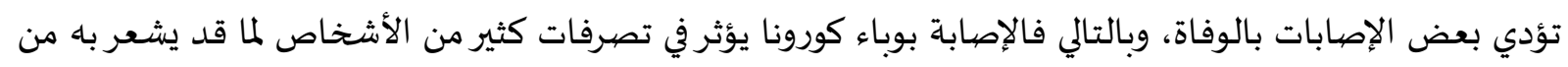

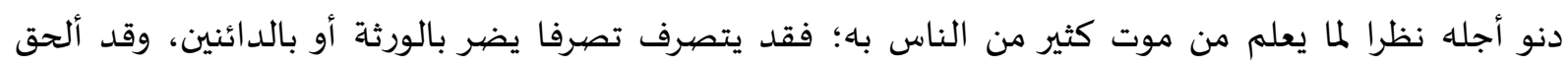

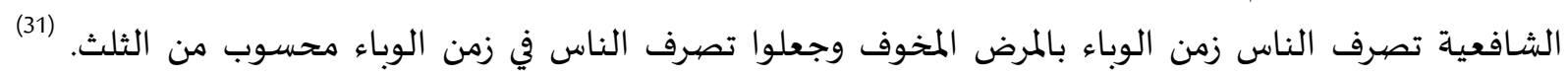

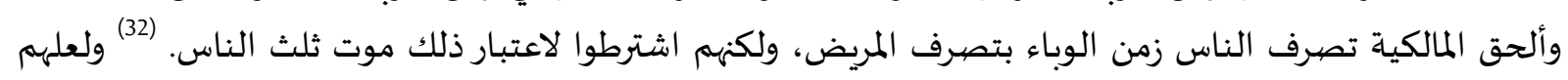

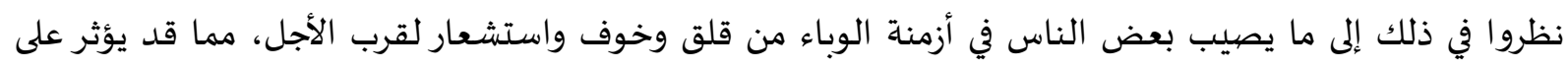
تصرفاته.

وفي هذا البحث نتناول حكم تصرف المصاب بوباء كورونا في عقود المعاوضات المالية (عقد البيع أنموذجا)

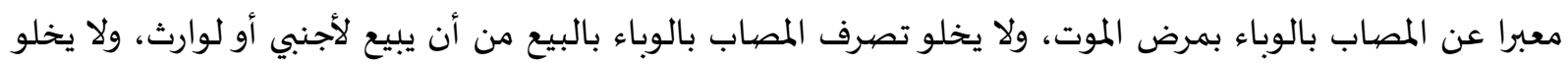

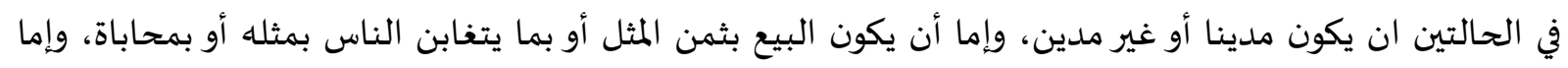

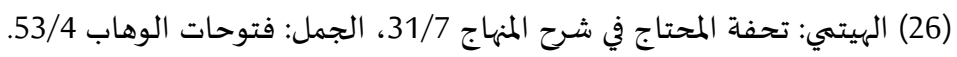

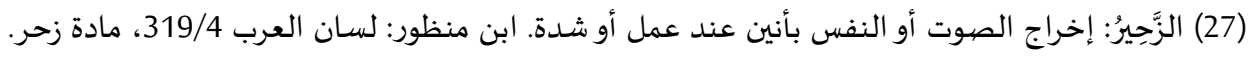

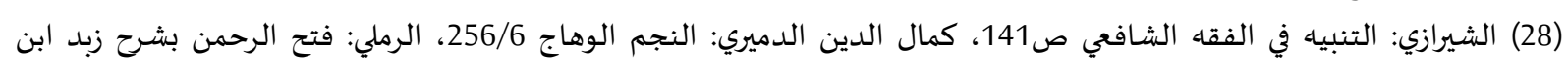
رسلان 603.

(29) المرداوي: الإنصاف 165/7، البهوتي: كشاف القناع 323/4.

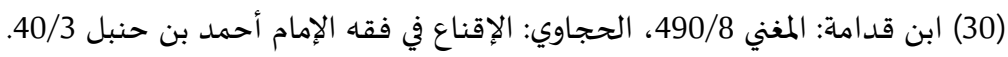

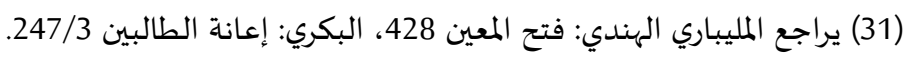

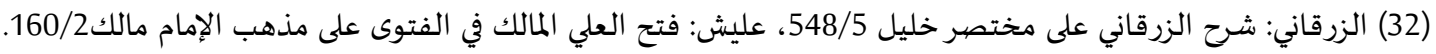


أن تكون المحاباة بالثلث أو بما يزيد عن الثلث، ولكل حالة من هذه الحالات حكم، نبينه - بمشيئة الله خلال هذا

\section{المبحث الثاني: حكم بيع المريض مرض الموت للأجنبي وفيه مطلبان:}

\section{المطلب الأول: حكم بيع المريض غير المدين للأجنبي:}

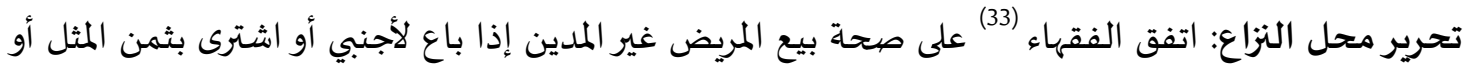

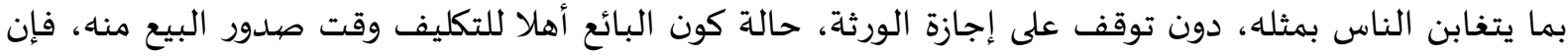
كان باه ما يؤثر على صحة تصرفه كخلل بعقله فإن تصرفه لا ينفذ.

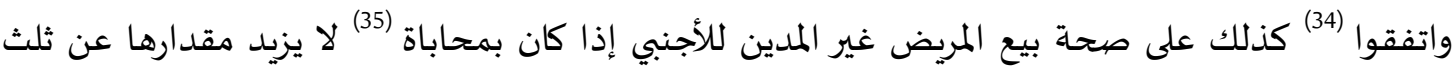

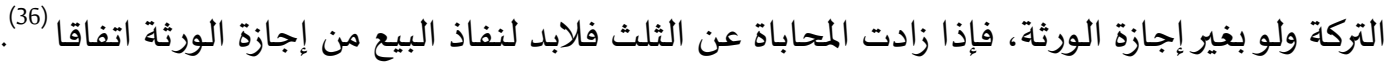

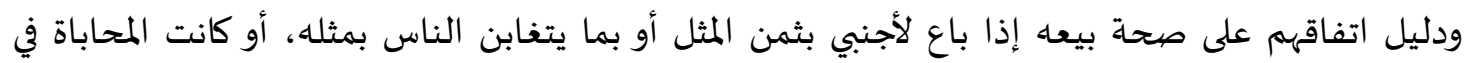
حدود الثلث: السنة والقياس والمعقول:

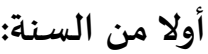

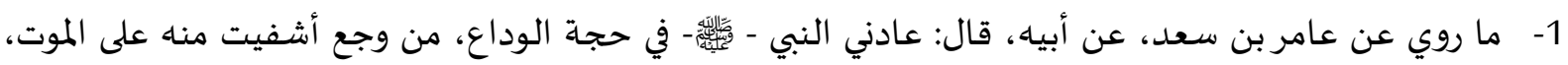

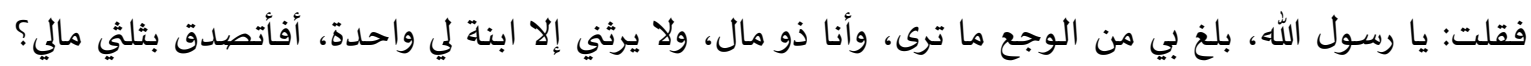

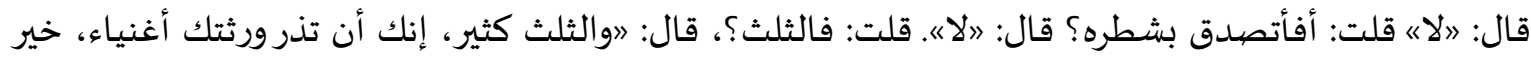

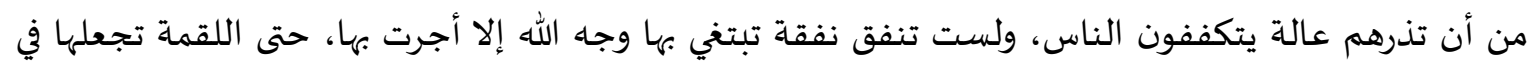

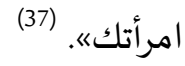
وجه الدلالة من الحديث: الحديث دليل على شرعية الوصية بالثلث، وأنه لا يمنع منه الميت. (38) كما إن

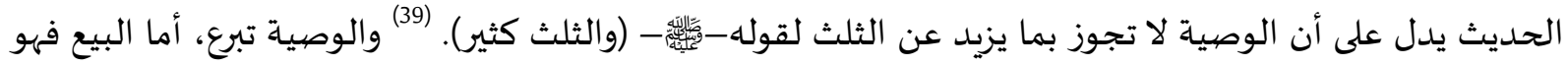

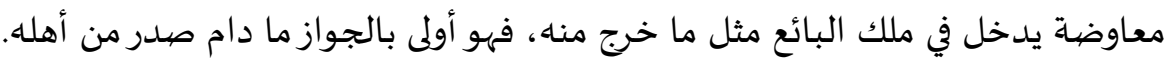

(33) ابن الهمام: فتح القدير304/9، لجنة من فقهاء الحنفية: مجلة الأحكام العدلية المادة (394)، الإمام مالك: المدونة 122/3،

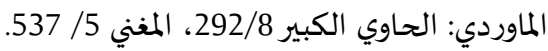

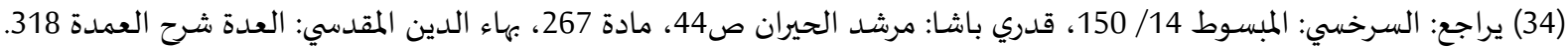
(35) ) المحاباة لغةة: يقال حاباه محاباة وحباء: أي نصره، واختصاه، ومال إلياه، ويقال حاباه في البيع ونحوه: أي تساهل معاه وساهحاء

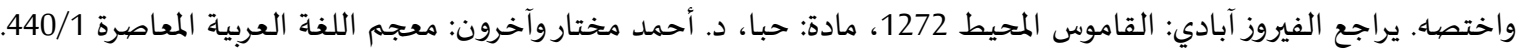

اصطلاحا: البيع بدون ثمن المثل. النووي: تحرير ألفاظ التنبيه 241. (36) المحاباة في البيع تعد تبرع وهي بمنزلة الوصية فإذا زادت عن الثلث فلابد من إجازة الورثة. يراجع الجصاص: شرح مختصر

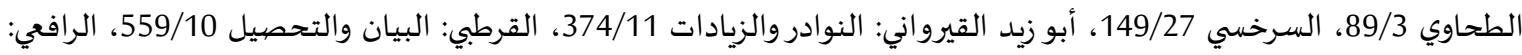

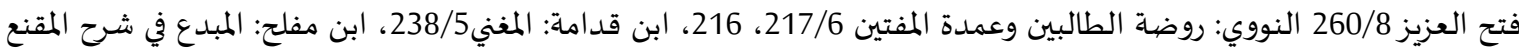

(37) البخاري: الجامع المسند الصحيح، كتاب المفازي، باب حجة الوداع، حديث 4409، ج178/5، مسلم: المسند الصحيح، كتاب

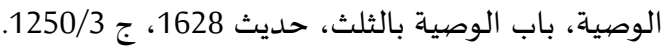

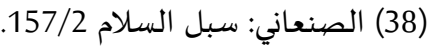


2- ما روي عن عمران بن حصين، أن رجلا من الأنصار أعتق ستة أعبد له عند موته، ولم يكن له مال غيرهم، فبلغ

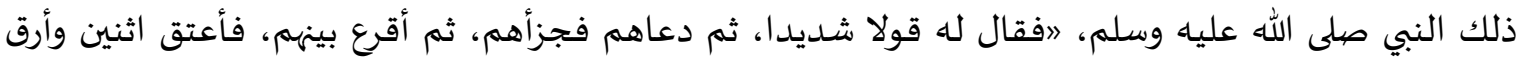

وجه الدلالة من الحديث: في هذا بيان أن حكم عتق البتات في المرض الذي يموت باه المعتق حكم الوصايا

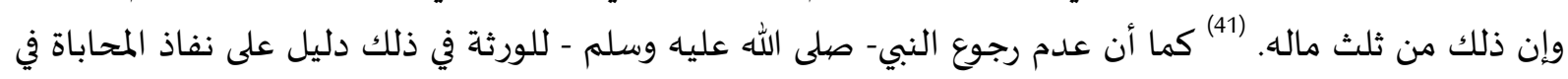

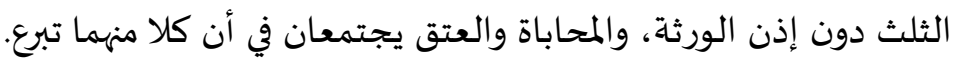

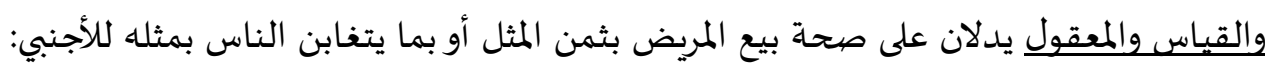

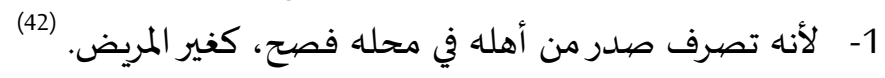

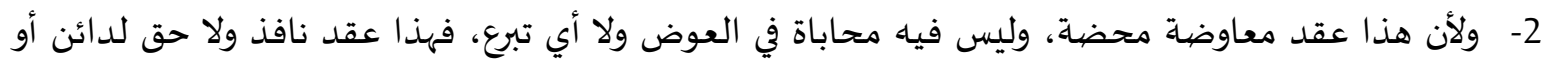

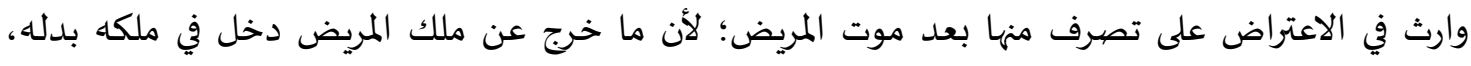

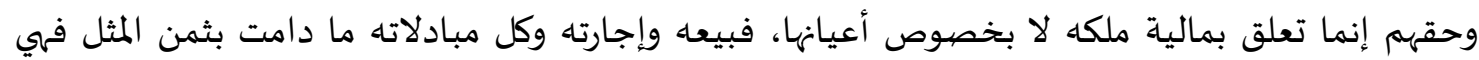
نافذة. أما دليل الاتفاق على صحة بيع المريض ونفاذه إذا كانت المحاباة بأكثر من الثلث إذا أجازه الورثة فمن المعقول:

- - أن التبرع بما زاد عن الثلث إنما هو لحق الورثة، فإذا أجاز الورثة ذلك فقد رضوا بإسقاط حقهم. (44)

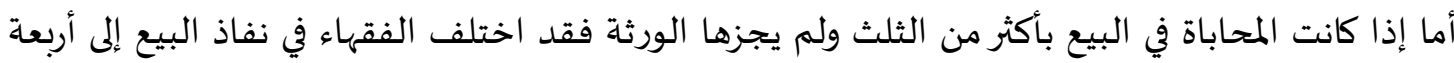

القول الأول: ذهب الحنفية (45) إلى أنه إذا كان البدلان ليسا من جنس واحد وكانت المحاباة بأكثر من الثلث،

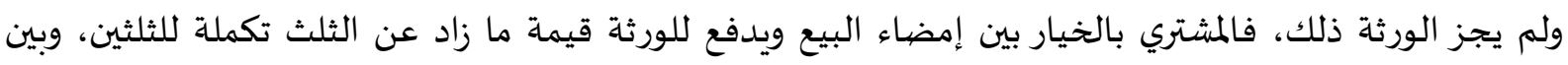
فسخ البيع ورد المبيع للورثة. وإذا كان البدلان من جنس واحد من الأموال الربوية، فليس من حق الورثة اجبار المشتري بدفع الزائد عن

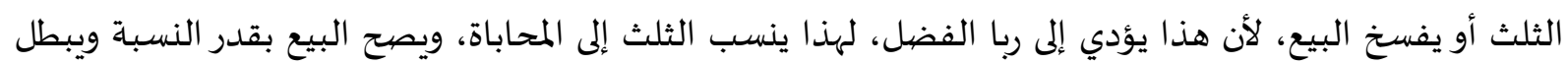

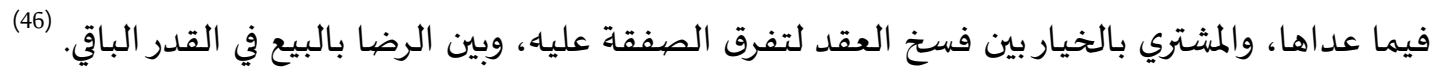
ويستدل لذلك بالسنة والمعقول:

أما من السنة: فحديث عامر بن سعد، وحديث عمران بن حصين المعين السابقين. (47)

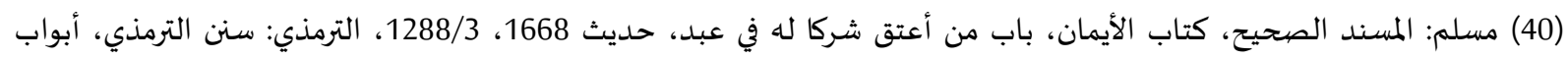

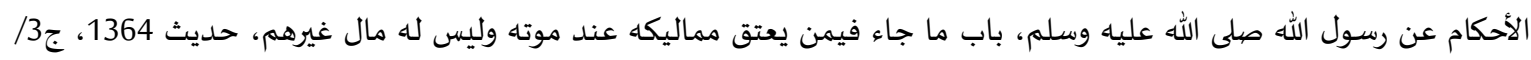

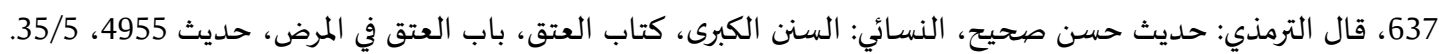

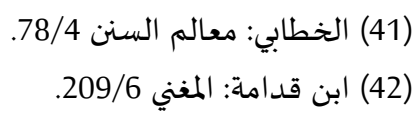

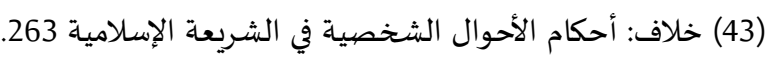

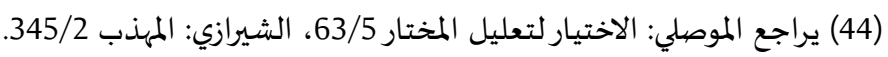

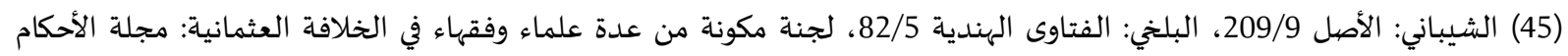

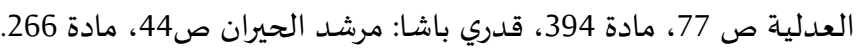
(46) يراجع السرخسي: المبسوط 59/29. 
وجه الدلالة من الحديث الأول: أن النبي - صلى الله عليه وسلم - لم يجز لسعد بن أبي وقاص أن يوصي

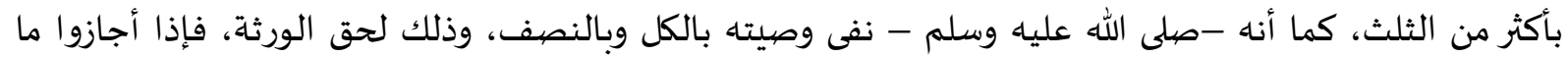

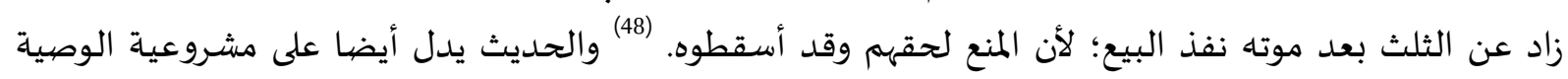

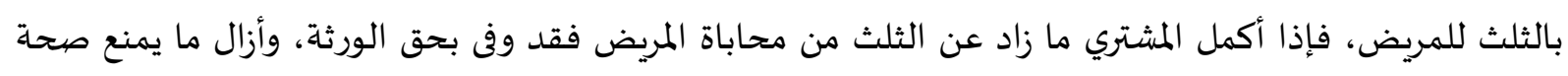

وجه الدلالة من الحديث الثاني: في الحديث دليل على جواز تبرع المريض في حدود الثلث، حيث جاء في ألثي

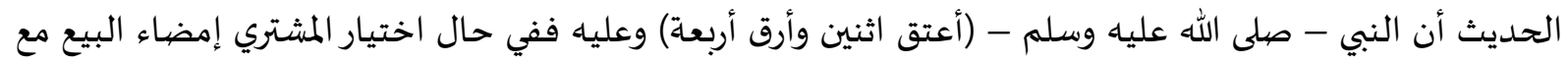

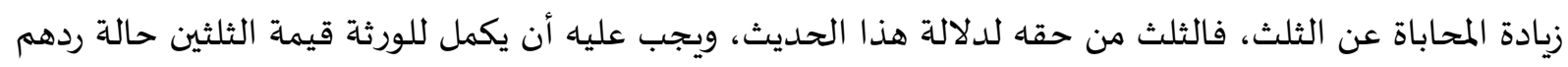

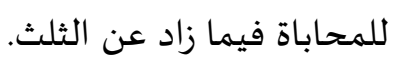

دليل المعقول: - أن من حق الورثة رد المحاباة فيما زاد عن الثلث؛ لأنه يضر بحقهم، فإذا أكمل المشتري قيمة الثلثين للورثة فقد

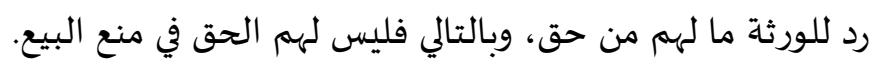

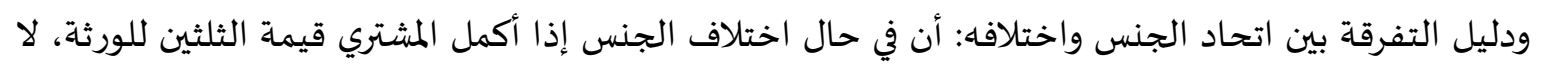

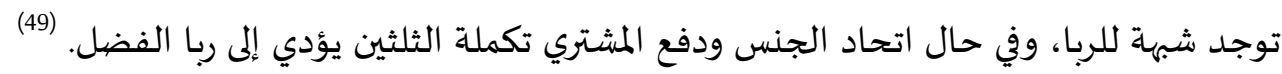

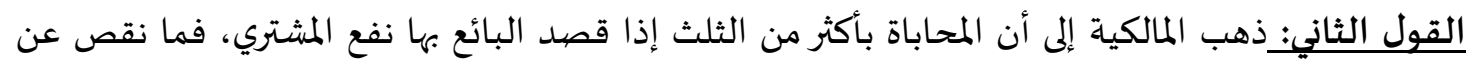

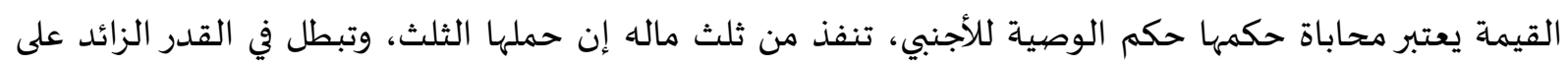

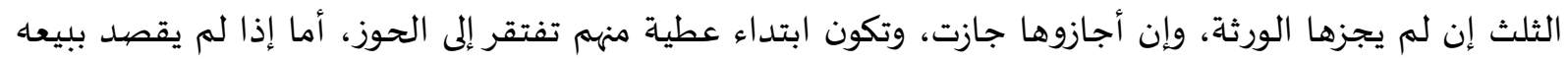

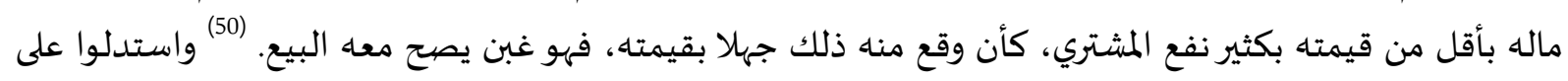

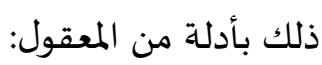

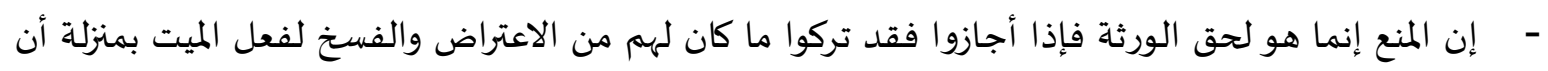
يأذنوا له قبل أن يوصي وبمنزلة حكم الثلث. - إن حقوقهم إنما تتعلق بما زاد على الثلث فليس لهم أن يتعدوه إلى ما لم تتعلق باه حقوقهم؛ لأن حقوقهم

تتعلق بثلثي المال بمرض الموصي، وإنما تتعلق حقوقهم بالثلث الباقي بموت مورثهم دون وصية.

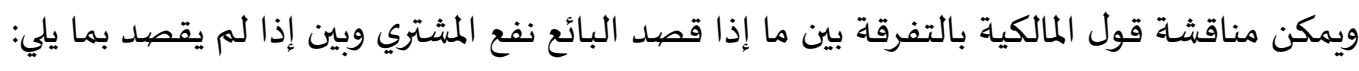
- بأن هذا أمر يصعب الاطلاع عليه، والأحكام لا تبنى على الاحتمالات.

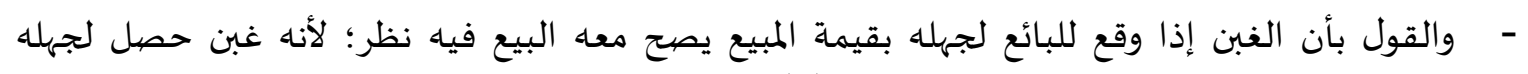

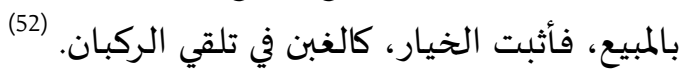


القول الثالث: ذهب الشافعية (53) إلى أن المحاباة في البيع إذا كانت بأكثر من ثلث ماله ولم يجزها الورثة،

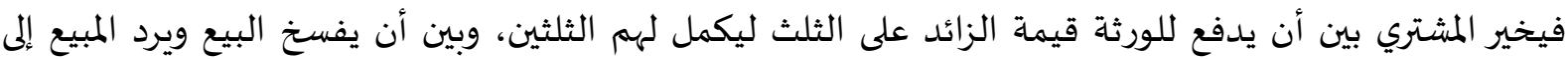
الورثة، هذا إذا كان المبيع قائما، أما إذا كان المبيع فائتا رد ما بين قيمة ما لا يتغابن الناس بمثله مما لم يحمله

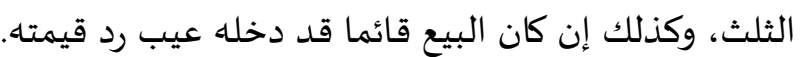

الأدلة:يمكن الاستدلال لمذهب الشافعية بنفس الأدلة المستدل بها لمذهب الحنفية من السنة.

\section{ويمكن مناقشـة مذهب الشافعية بما يلي:}

- - - أن عدم التفرقة بين جنس المبيع قد يؤدي إلى الربا في حال اتحاد الجنس الربوي وهذا محرم شرعا؛ ففي

الحديث (الذهب بالذهب والفضة بالفضة....... يدا بيد مثلا بمثل فمن زاد أو ازداد فقد أربى).

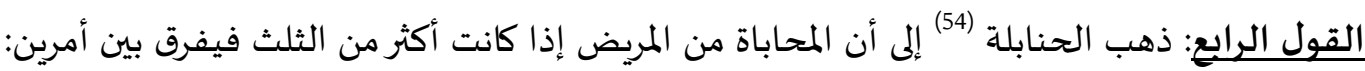

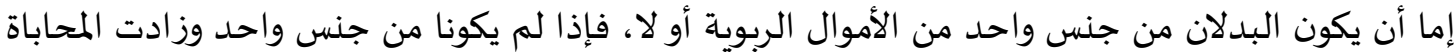
عن الثلث ولم يجزها الورثة بطل البيع في قدر الزيادة على الثلث وسلم الباقي للمشتري، والمشتري بالخيار بين الفسخ؛ لتفرق الصفقة عليه، وبين أن يأخذ ما سلم له من المبيع. أما إذا كان البدلان من جنس واحد من الأموال الربوية غير الثمنين وزادت المحاباة عن الثلث، ولم يجزها الورثة فينسب الثلث إلى المحاباة، ويصح البيع بقدر النسبة ويبطل ما عداها، ويكون المشتري بالخيار بين الفسخ للبيع لتفرق الصفقة عليه، وبين الرضا بالبيع في القدر الباقي، لئلا يؤدي ذلك إلى الربا.

\section{ويستدل لهذا المذهب بالمعقول:}

- في حالة اختلاف الجنس مع زيادة المحاباة عن الثلث، وعدم إجازة الورثة فالبيع يبطل في المقدار الزائد عن

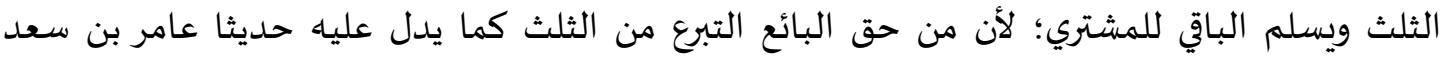
وعمران بن حصين السابقين. - ـ - أما إذا كان البدلان ربويان من جنس واحد فليس للورثة أن يلزموا المشتري بدفع الزائد عن الثلث أو يفسخ

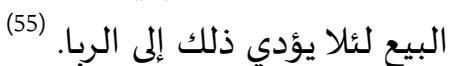
ويمكن مناقشـة هذا القول بما يلي: القول بإبطال البيع في قدر الزائد على الثلث في حال كان البدلان من جنس واحد لعلة منع الشرع بالتبرع بما زاد عن الثلث يجاب على ذلك: بأن إمضاء البيع في هذه الحالة مع تخيير المشتري بين فسخ البيع، وبين تكملة ما زاد عن الثلثين فيه إعمال للشرع ورفع الضرر عن جميع الأطراف؛ حيث إن فيه إعطاء البائع المريض حقه في التصرف فيما يملك بما لا يتعارض مع الشرع، وتصحيح للخطأ الواقع منه بالمحاباة بما زاد عن الثلث وذلك بدفع المشتري قيمة ما زاد عن الثلثين من محاباة للورثة، وعليه فإبطال البيع فيما زاد عن الثلث أمر مردود لإمكان معالجته بما يتفق مع مصلحة الجميع.

الترجيح:بعد عرض أقوال الفقهاء في المسألة فإن ما أميل إلى ترجيحه هو ما ذهب إليه الحنفية من القول بأن البدلين إذا لم يكونا من جنس واحد وكانت المحاباة بأكثر من الثلث، ولم يجز الورثة ذلك، فالمشتري بالخيار بين

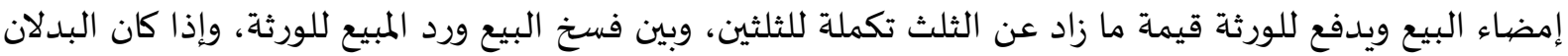


من جنس واحد من الأموال الربوية، فليس من حق الورثة اجبار المشتري بدفح الزائد عن الثلث أو فسخ البيع، لأن

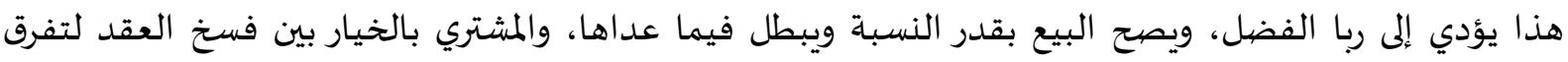
الصفقة عليه، وبين الرضا بالبيع في القدر الباقي.

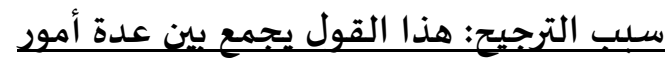

- العمل بالسنة النبوية في عدم إجازة التبرع بما زاد عن الثلث إلا بإجازة الورثئ.

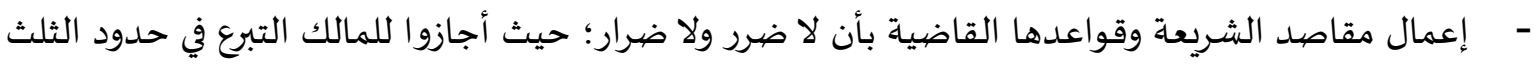

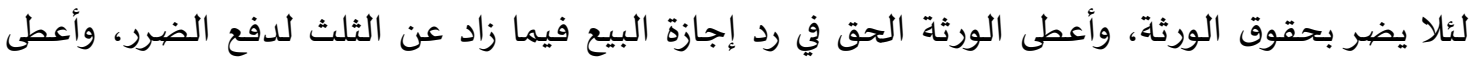

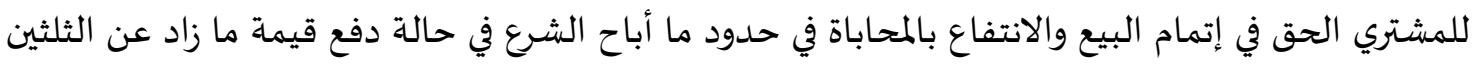

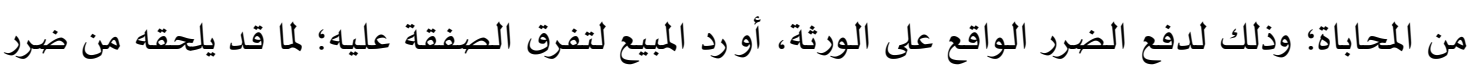
تبعا لجنس المبيع. - كما أن التفرقة بين ما إذا كان البدلان من جنس واحد أو لا فيهاء تجنب للوقوع في كبيرة الربا.

المطلب الثاني: في بيع المريض المدين للأجنبي اتفق الفقهاء (56) على أن المريض إذإن الماين باع شيئا من ماله لأجنبي بثمن المثل وكان عليه دين مستغرق لجميع تركته فإن البيع صحيح، ولا يحق للدائنين الاعتراض عليه.

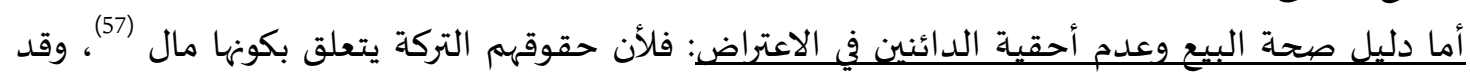

دخل في ملك المدين بهذا البيع مثل ما خرج منه ومساو لها في القيمة. (58)

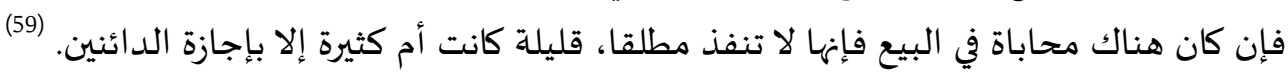

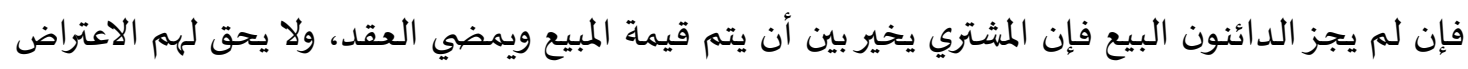

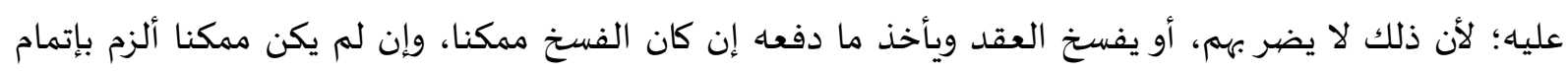
الثمن إلى أن يبلغ القيمة. (60)

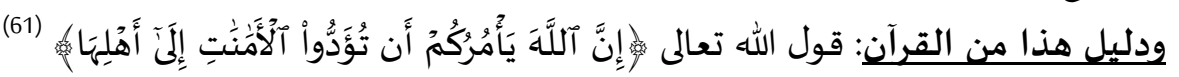

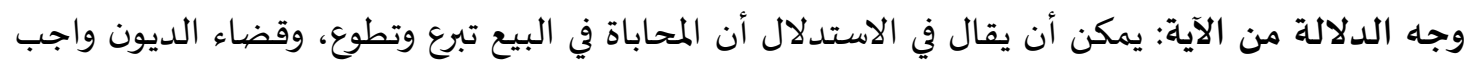
مأمور باه ويدخل تحت الأمانات المأمور بأدائها، فتبطل كل محابهابة المكاة في البيع من المريض تؤثر على حقوق الدائنين.

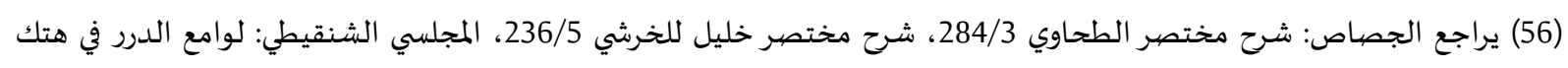

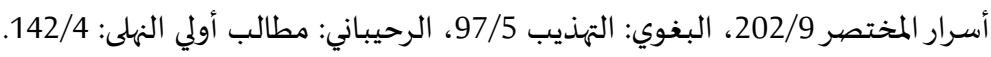

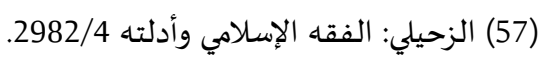

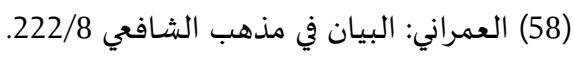

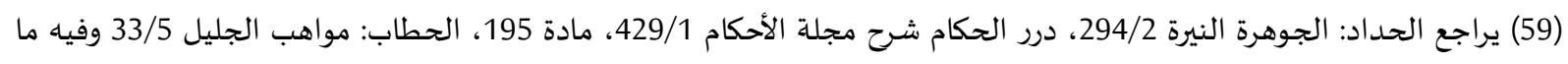

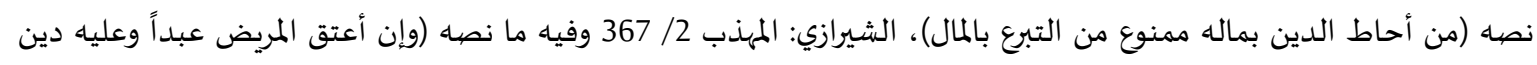

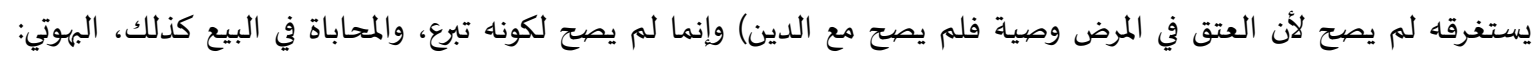

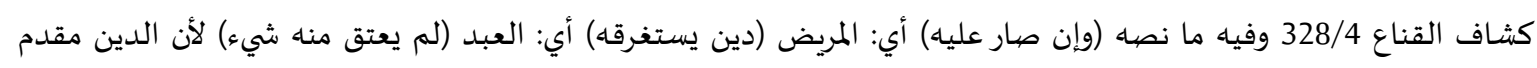

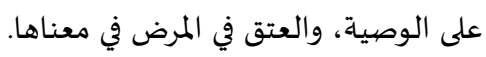

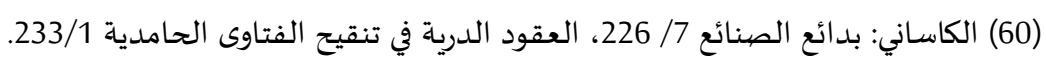

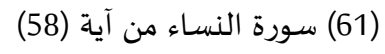




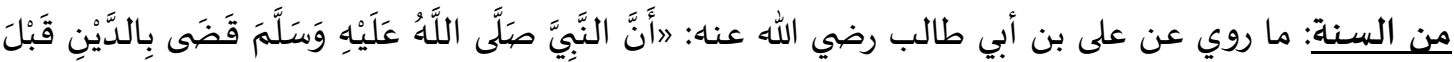

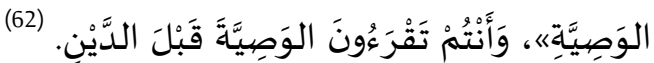

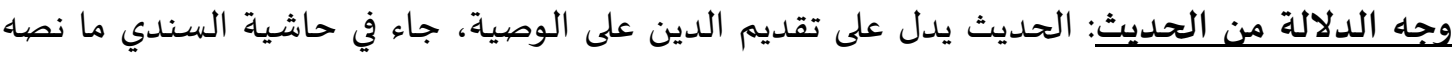

(قوله: (بالدين) أي: بأدائه قبل إخراج الوصية (وأنتم تقرؤونها) أي: فلا تفهموا من التقديم = =اللفظي التقديم

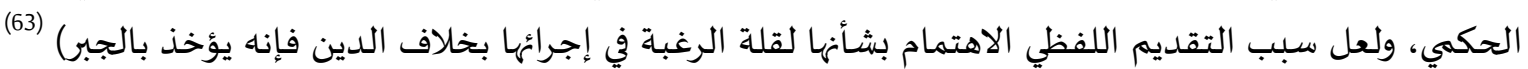
أما بداية الآية بالوصية قبل الدين، فليس يوجب تقديم اللفظ بالوصية قبل الدين أن تكون مقدمة على الدين، وإنما يوجب الكلام أن يكون الدين والوصية تخرجان قبل قسم الميراث؛ لأنه لما قيل من بعد كذا وكذا علم

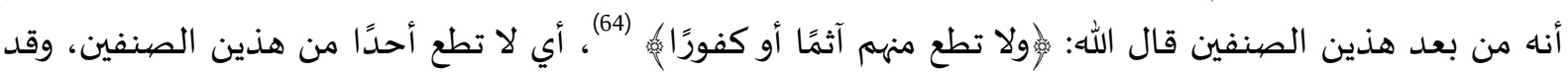
يقول الرجل: مررت بفلان وفلان فيجوز أن يكون الذى بدأ بتسميته مر به أخيرًا ويجوز أن يكون مر به أولا؛ لأنه ليس

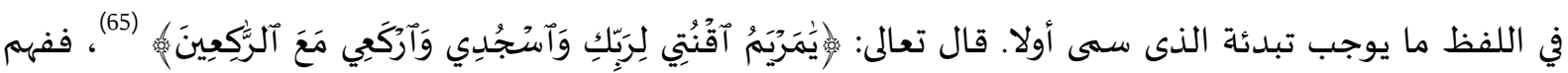

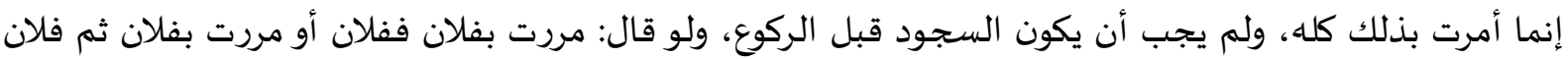

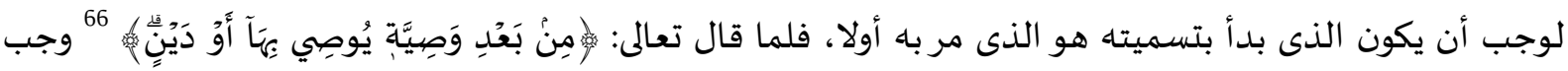

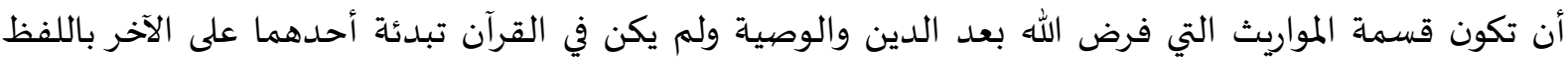

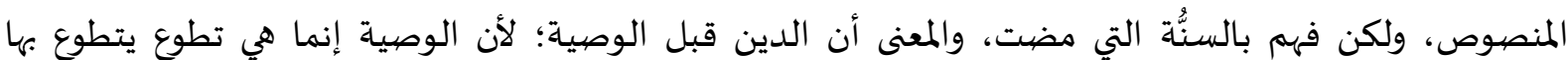

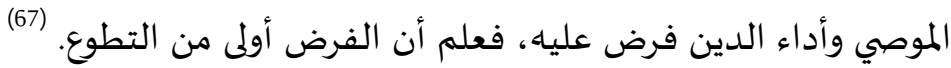

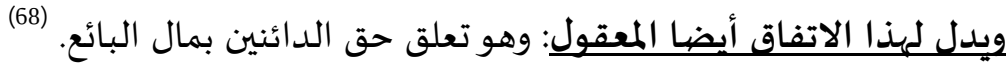

المبحث الثالث: بيع المريض لوارثه وفيه ثلاثة مطالب

المطلب الأول: بيع المريض غير المدين لوارثه بثمن المثل أو بما يتغابن الناس بمثله:

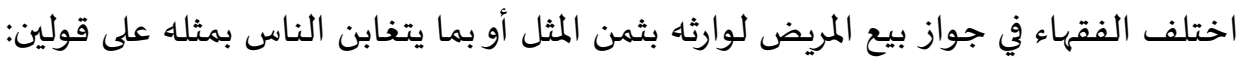

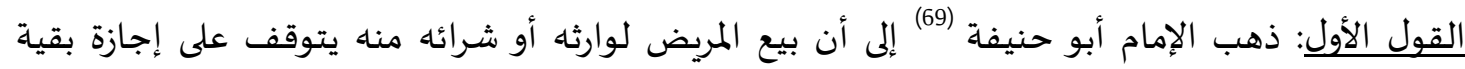
الورثة ولو كان ذلك بثمن المثل دون محاباة واستدل على ذلك بأدلة من القياس والمعقول:

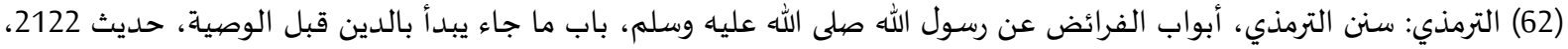

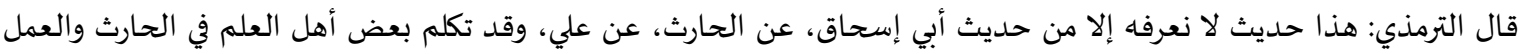

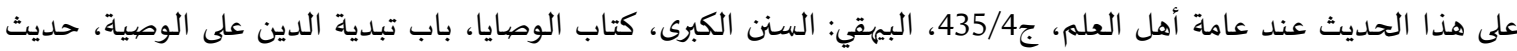

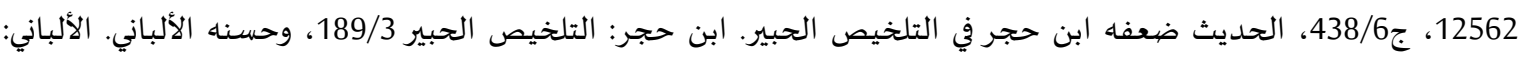

إرواء الغليل 131/6.

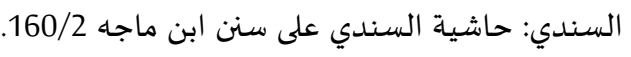

(64) سورة الإنسان من آية (65) (65) السنائ

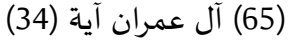

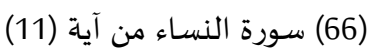

(67) ابن بطال: شرح صحيح البخاري 160/8.

(68) الزحيلي: الفقه الإسلامي وأدلته النهاري 2982/4.

(69) السرخسي: المبسوط 150/14، الزيلعي: تبيين الحقائق 214/5، البابرتي: العناية شرح الهداية 302/9. 
أولا من القياس: قياسا على وصيته بأن يعطى أحد ورثته هذه الدار بنصيباه من الميراث وهذا غير جائز؛ لأن

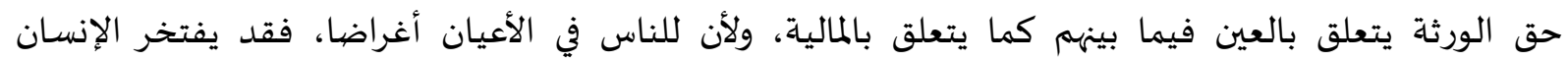

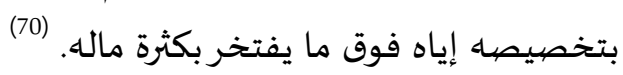
ويمكن مناقشة هذا الدليل بما بلي:

إنه قياس مع الفارق؛ لأن الوصية للوارث تجوز إذا أجازها الورثة، كما أن البيع يدخل في ملك البائع مثل ما خرج مناء.

أما قوله - رحماه الله - إن حق الورثة يتعلق بالعين فيما بينهم كما يتعلق بالمالية: نوقش بما بلي:

إن اعتراض الورثة على المريض في المقدار لا في الأعيان ألا تراه لو باع أجنبي بثمن مثله صح البيع مع انتقال

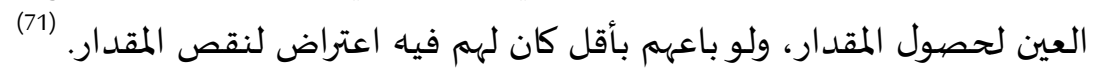

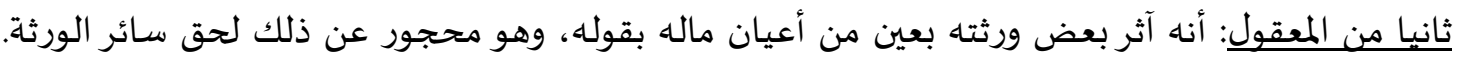

ونوقش هذا الاستدلال بما يلي: أنه إنما حجر عليه في التبرع في حقه فلم يمنع الصحة فيما سواه كالأجنبي

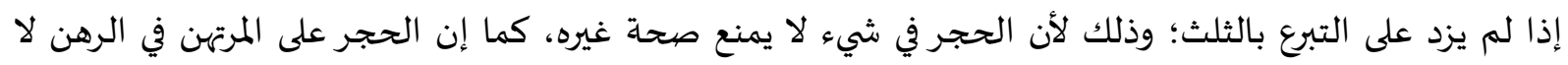

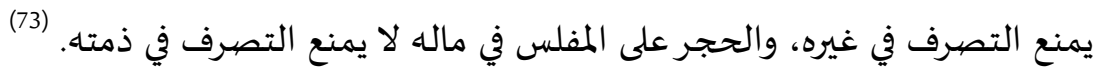

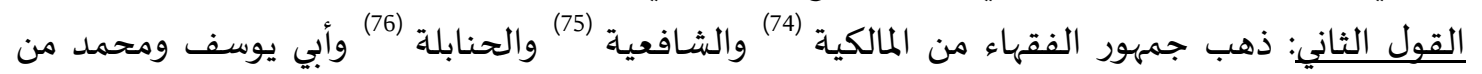
الحنفية (77) إلى صحة ونفاذ بيع المريض مرض الموت لوارثه بثمن المثل دون توقف على إجازة أحد الورثة، واستدلوا على ذلك بأدلة من القياس والمعقول: أولا من القياس: القياس على صحاة بيع المريض للأجنبي بثمن المثل، وليس للورثة حق الاعتراض على ذلك.

$$
\text { - }
$$

- لأنه ليس في تصرفه إبطال حق الورثة عن شيء مما تعلق حقهم به وهو المالية، والوارث والأجنبي في مثل هذا

التصرف سواء كما لو أعانه ببدنه. (80)

(70) السرخسي: المبسوط 150/14 بتصرف، الزيلعي تبين الحقائق 214/5

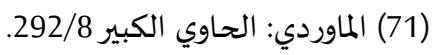

(72) السرخسي: المبسوط 150/14، الزيلعي تبين الحقائق 214/5. 280/5 الشاشي ابو بكر: حلية العلماء في معرفة مذاهب الفقهاء

) (744الإمام مالك: المدونة 122/3، ابن الحاجب: جامع الأمهات 338، المواق: التاج والإكليل

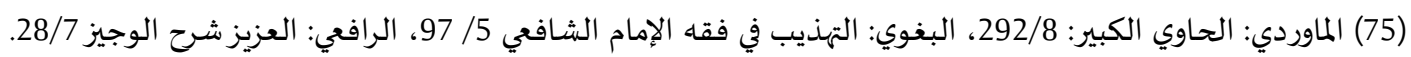

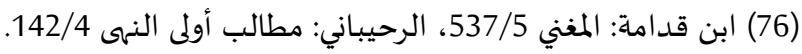

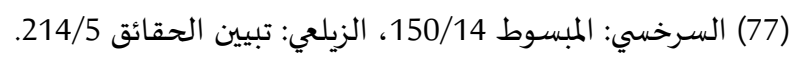
(78) الماوردي: الحاوي الكبير 292/8. (79) الرحيباني: مطالب أولى النهى 142/4)

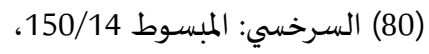


- إنه لا تبرع فيه؛ ولذا يجوز بيع الزائد على الثلث بثمن المثل من الأجنبي. (81)

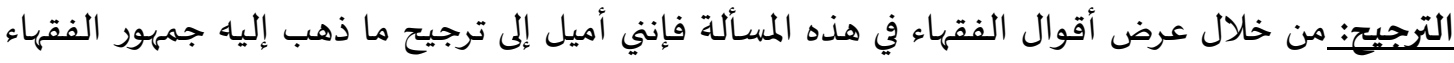

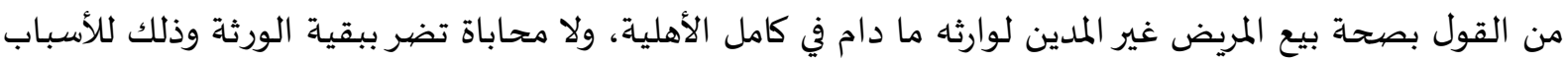
التالية:

- قوة أدلتهم، وضعف أدلة المخالفين والرد عليها، وسلامة أدلتهم من المعارضة. - لأن هذا القول يتفق مع عموم الآيات ونصوص السنة النبوية والقواعد الشرعية الدالة على إباحة البيع في

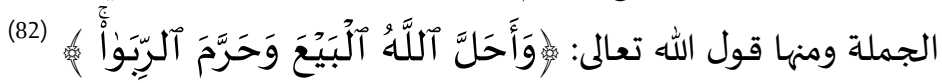

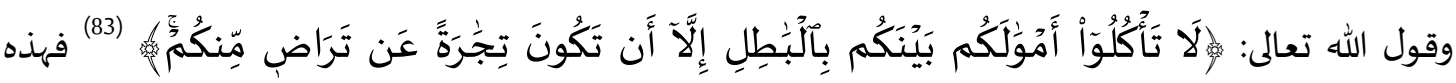
الآيات تدل على حل البيع عموما، ومن النصوص النبوية الدالة على جواز بيع المريض: ما روي عن عبادة بن

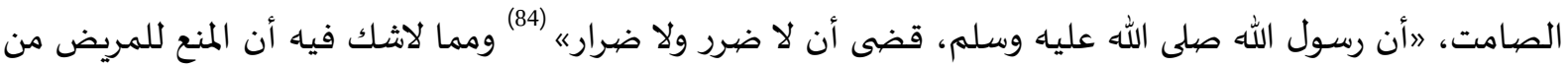
البيع ولو كان مرض الموت بغير مبرر شرعي يضره.

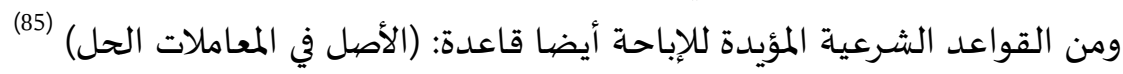

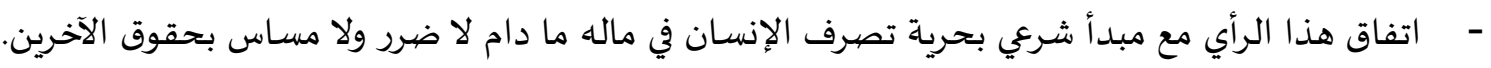

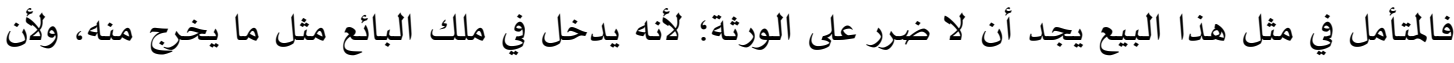

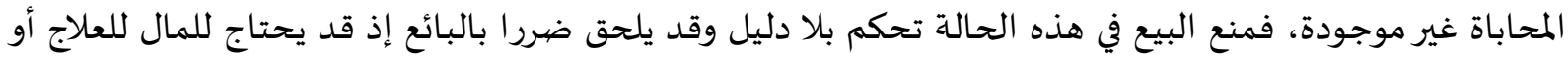

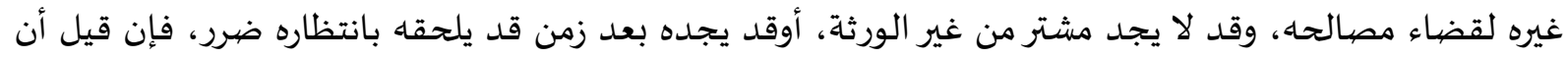

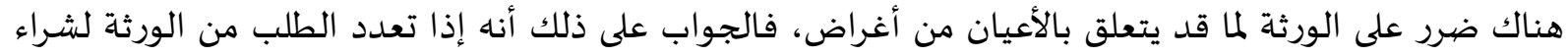

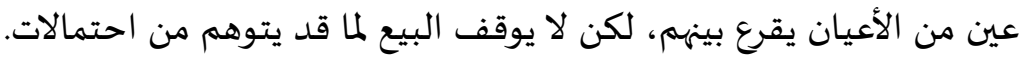

المطلب الثاني: بيع المريض غير المدين لوارثه مع المحاباة

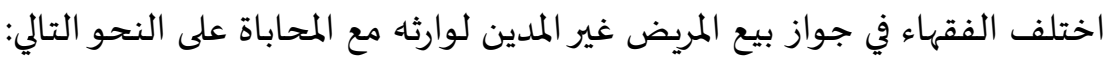

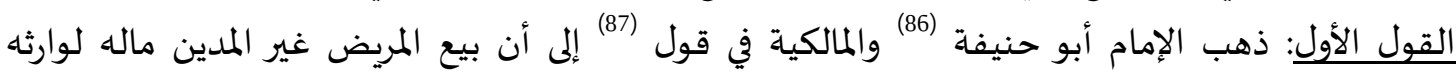
موقوف على إجازة الورثة فإن أجازوه نفذ وإن لم يجيزوه فالبيع باطل، واستدلوا لمذهيهيهم بالمعقول:

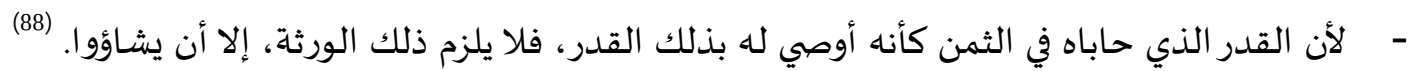

$$
\begin{aligned}
& \text { (81) الرافعي: العزيزشرح الوجيز28/7. } \\
& \text { (82) سورة البقرة من آية 275. } \\
& \text { (83) سورة النساء من آية } 29 .
\end{aligned}
$$

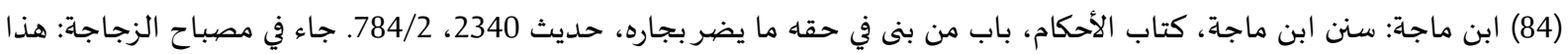

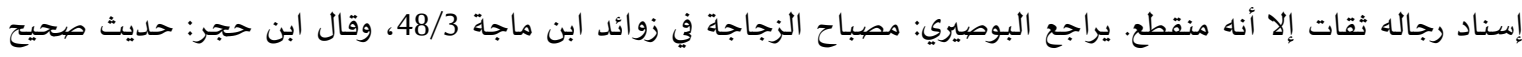

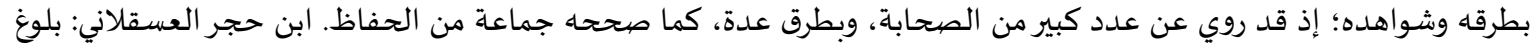

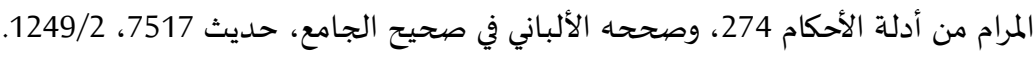

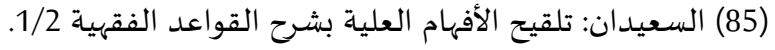

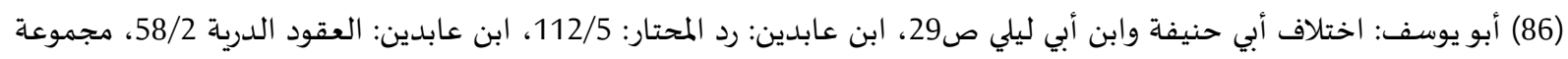

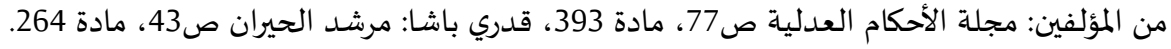

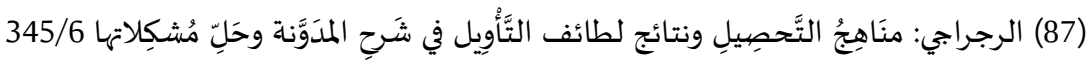
(88) نفس المرجع السابق ونفس الجزء والصفحة التحنة. 
ويمكن مناقشة هذا الدليل: بأن المشتري إذا دفع قيمة المحاباة، واتم قيمة المبيع أزيل مانع صحة البيع ورفع الضرر عن الورثة.

القول الثاني: ذهب أبو يوسف ومحمد (89) إلى أن بيع المريض لوارثه مع المحاباة لا يجوز إلا إذا أجازه

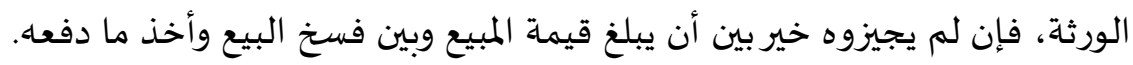

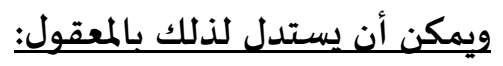

- وهو أنه إذا أتم قيمة المبيع فليس في ذلك إبطال لحق الورثة عن شيء مما يتعلق باه حقهم، وهو المالية،

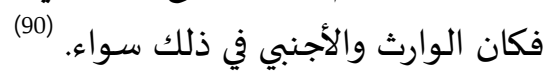
القول الثالث: ذهب المالكية (91) في قول آخر إلى أن أن بيع المريض لوارثانه بمحاباة في الثمن يتوقف على إجازة

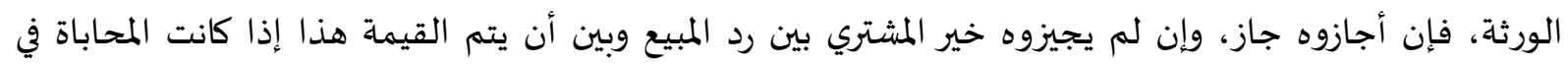

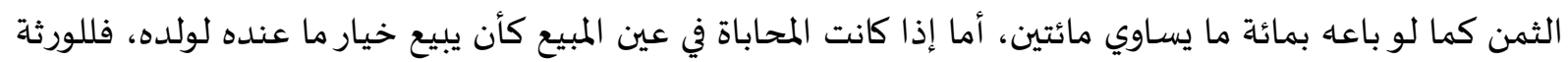

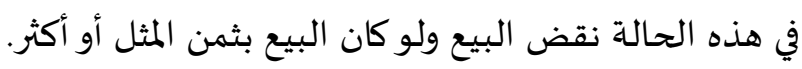

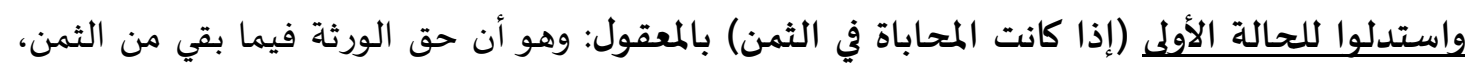
فإذا تم فلا حجة لهم. (92)

وقد يستدل للحالة الثانية: بأن بيع المريض لولده خيار ما عنده فيها تفضيل له عن بقية الورثة.

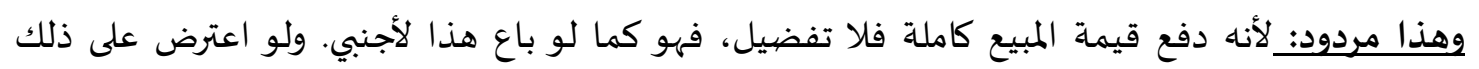
الورثة اقرع بينهم؛ منعا للتباغض والتحاسـد.

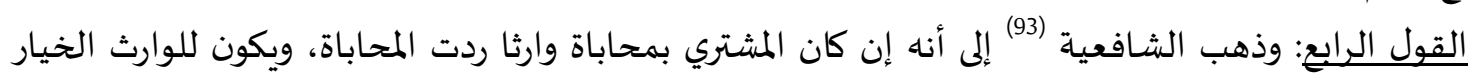

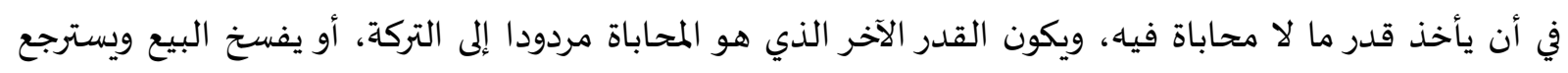

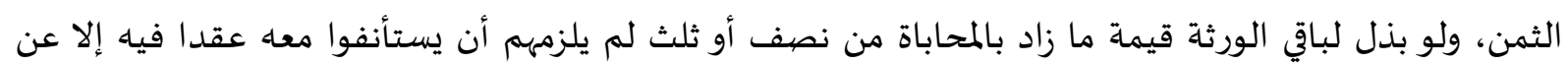
مراضاة.

\section{واستدلوا على ذلك بالمعقول:}

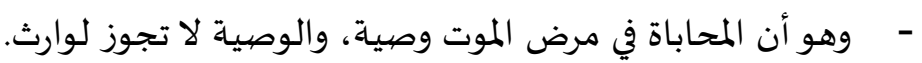

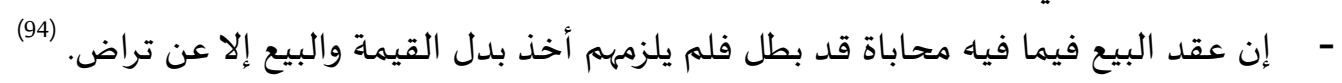

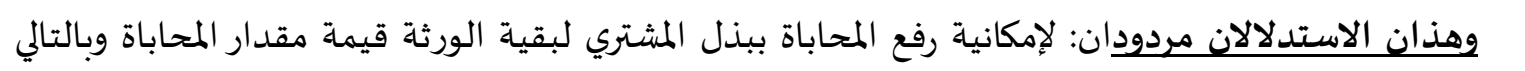
لا لا سبب لبطلان البيع. القول الخامس: إذا باع المريض لوارثه بمحاباة (95) فللحنابلة ثلاثة اقوال:

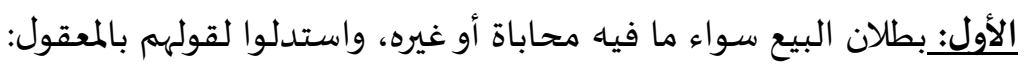

(89) ابن عابدين: رد المحتار على الدر المختار 112/5.

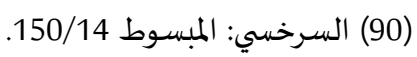
(91) الرجراجي: منَاهِجُ التَّحصِيلِ (92) الرجراجي: منَاهِجُ التَّحصِيلِ (93) يراجع الماوردي: الحاوي الكبير 292/8، لمنسي 293. (94) الماوردي: الحاوي الكبير 293/8) (95) ابن قدامة المفني 237/5، 238. 
1- لأن المشتري بذل الثمن في كل المبيح، فلم يصح في بعضيه، كما لو قال: بعتك هذا الثوب بعشرة. فقال: قبلت البيع في نصفيه. أو قال: قبلته بخمسئة.

2- ولأنه لم يمكن تصحيح البيع على الوجها الذي تواجبا عليه، فلم يصح، كتفريق الصفية.

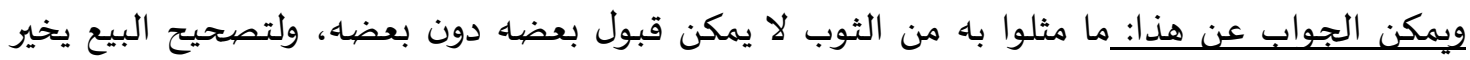

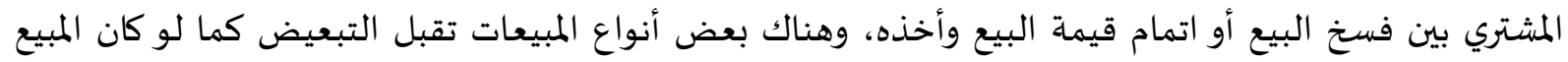
أرضا، فالمرجع هو جنس المبيع. الثاني: أنه يبطل البيع في قدر المحاباة ويصح فيما يقابل الثمن المسسى، وللمشتري الخيار بين الأخذ والفسخ

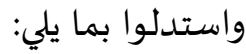
1- - الأن الصفقة تفرقت عليه.

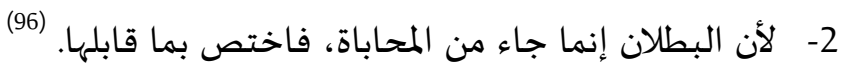
ويمكن أن يجاب عن الأول:بأن سبب التفريق هو المحاباة فإذا إتهاء ارتفت بدفع قيمتها فلا مجال للقول بتفريق الصفقة. ويججاب عن الثاني: بأنه إذا أتم المشتري قيمة المبيع ترتفع المحاباة.

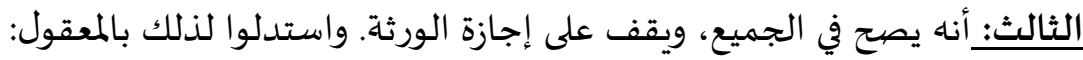

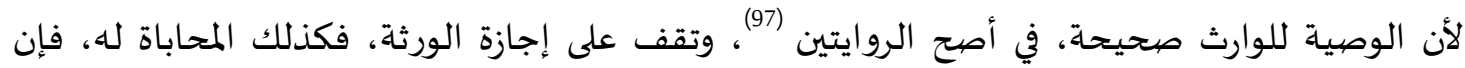

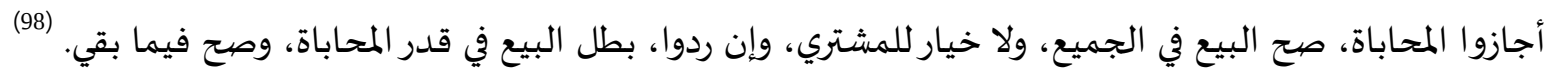

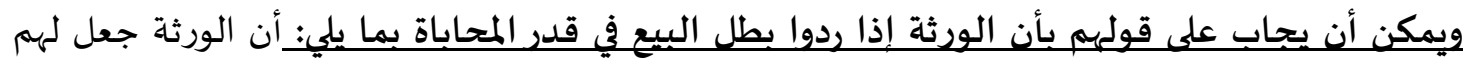
الحق في الاعتراض فقط للمحاباة التي تضر بحقهم، فإذا دفع المشتري قيمة المحاباة صح البيع في جميع المبيع، للوفاء بحق بقية الورثة. الترجيح: بعد عرض مذاهب الفقهاء وأدلة كل مذهب، والمناقشات الواردة عليها، فإن القول الذي أميل

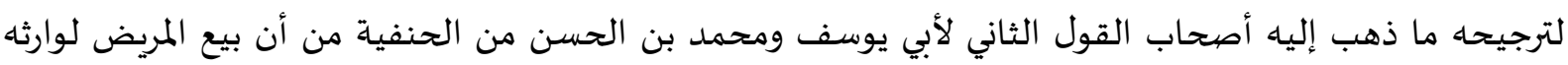

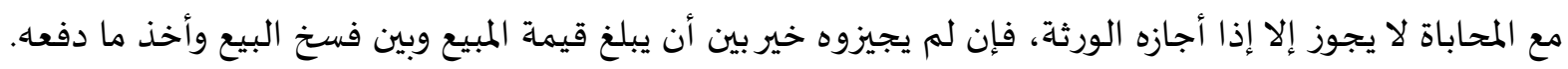

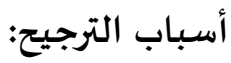
- قوة ما استندوا إليه من دليل، وسلامته من المعارضية. - - - مبعف أدلة المخالفين والرد عليها.

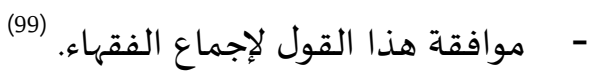
- موافقة هذا القول للقواعد الشرعية ومن ذلك قاعدة: الضرر يزال (100)، ففي هذه المسألة رفع الضرر وهو المّاء

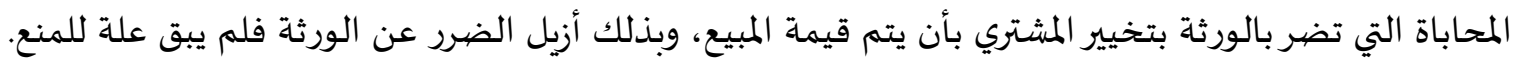

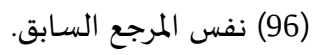

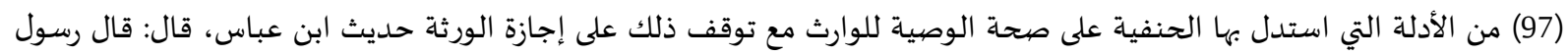

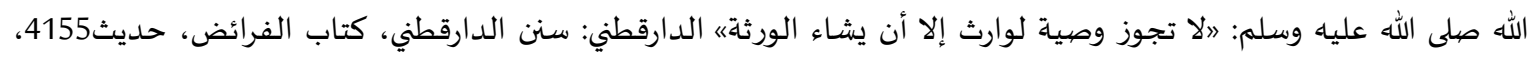

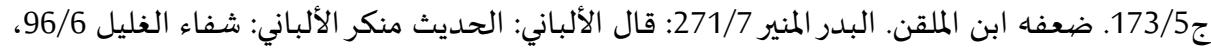

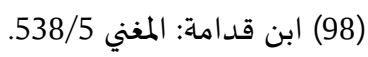

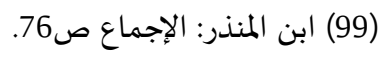


المطلب الثالث: حكم بيع المريض المدين لوارثة

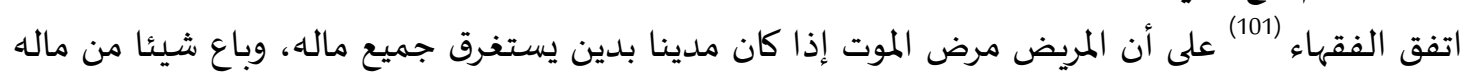
لوارثاء بثمن المثل أن بيعاه صحيح نافذ، سواء أجازه الغرماء أم لاء.

دليل اتفاق الفقهاء على صحة بيع المريض المدين بثمن المثل المعقول: - - - إن حق الغرماء متعلق بمالية التركة لا بأعياها. (102) -

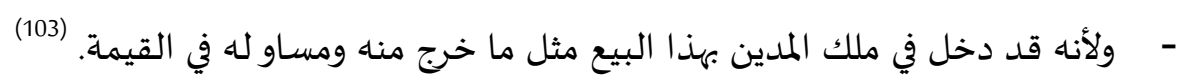

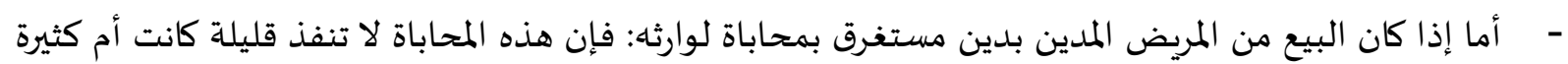

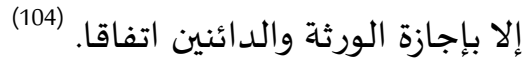

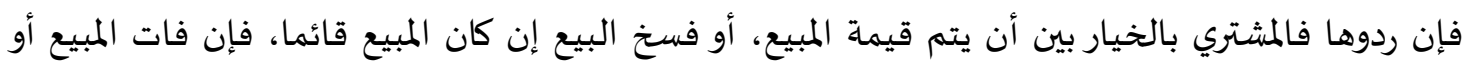
بعضيا تحت يده، ألزم بإتمام قيمة المبيع. (105)

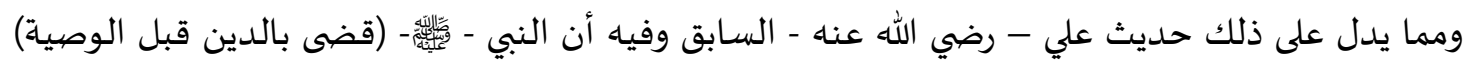

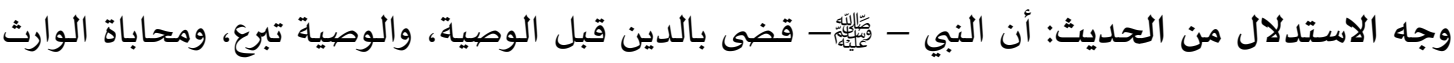
في البيع تبرع، فلا ينفذ هذا التبرع قبل قضياء الديون. كما يدل لذلك المعقول: فإن قضاء الديون واجب، والواجب مقدم على التبرع، ولأن ذلك يضر بحقوقهم.

$$
\text { المبحث الرابع: حكم الشفعة (107) في مبيع المريض بالقيمة أو المحاباة }
$$

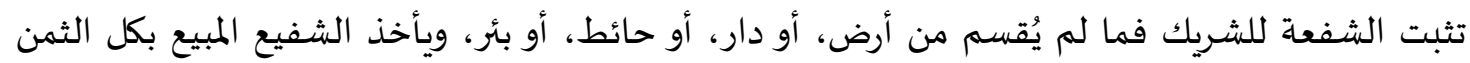

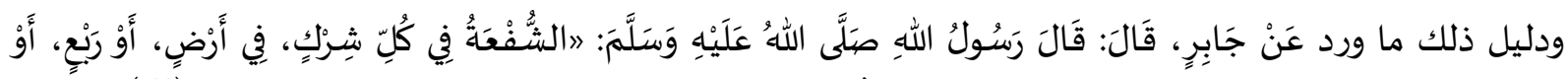

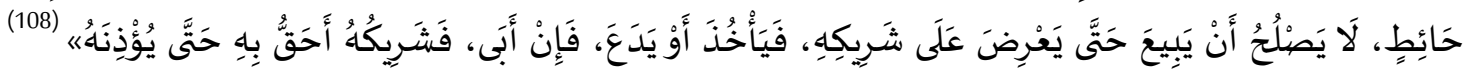

28/1) ابن الملقن: الأشباه والنظائر (101) السرخسي 151/14، كشف الأسرار 311/3وما بعدها، ددر الحكام شرح مجلة الأحكام 427/1 مادة 393، الإمام مالك:

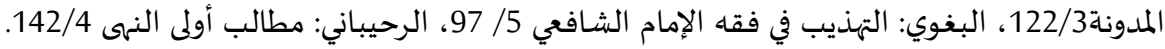

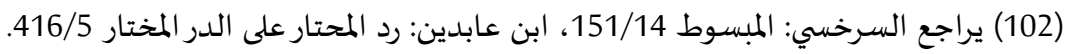
122/8 (103) العمراني: البيان. (104) يراجع الكاساني: بدائع الصنائع 226/7، الخرشي: شرح مختصر خليل 262/5، العمراني: البيان 378/3، 378/3، الكردي المهراني: تحرير

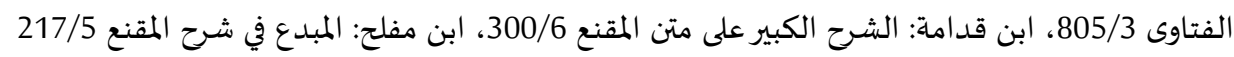
226/7 (105) الكاساني: بدائع الصنائئ

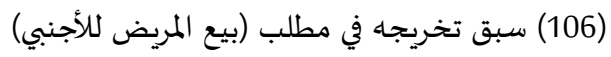
(107) الشفعة لغة: خلاف الوتر، وهو الزوج. تقول: كان وترا فشفعته شفعا. وشفع الوتر من العدد شفعا: صيره زوجا، وشفع لي يشفع

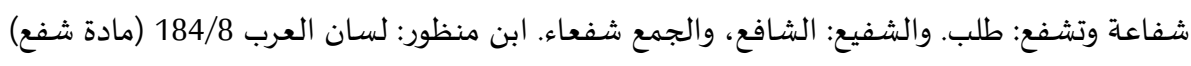
الشفعة اصطلاحا: استحقاق شريك أخذ مبيع شريكه بثمنه. الرصاع: شرح حدود ابن عرفة ص356.

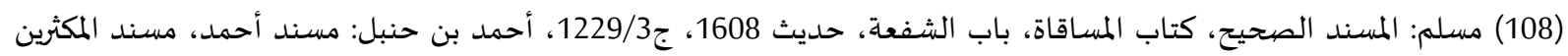

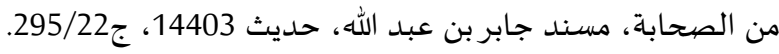


وجه الدلالة من الحديث: في الحديث دليل على أنه لا يحل للشريك بيع حصته حتى يعرض على شريكاه، وأنه محرم عليه البيع قبل عرضهاه (109)

إذا باع المميض حصته من دار أو نحوها لم يخل من أحد أمرين إما أن يكون البيع بثمن المثل، أو بالمحاباةً بأقل من ثمن المثل بالمحاباة، فالكلام في حكم الشفعة في مبيع دالمر المريض ينقسم إلى فرعين:

\section{الفرع الأول: حكم الشفعة في مبيع المريض بالقيمة}

إذا تم البيع من المريض بثمن المثل لوارثه أو لأجنبي فقد اختلف الفقهاء في صحة الشفعة إلى قولين:

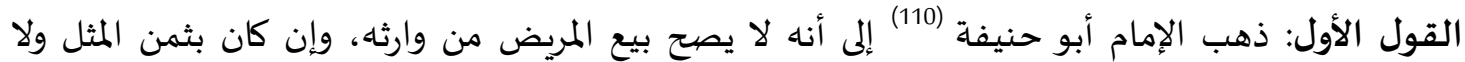

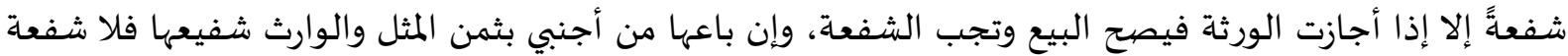
للوارث عنده واستدل لذلك بالمعقول: - - ملأن بيع المريض مرض الموت عينا من أعيان ماله لوارثه فاسـد عنده إلا إذا أجاز الورثة، وإن كان بمثل القيمة ولا شفعة له في البيع الفاسـد

ويرد على هذا الدليل: بما سبق ذكره من أليع الفاسلة الجمههور الفقهاء. (112)

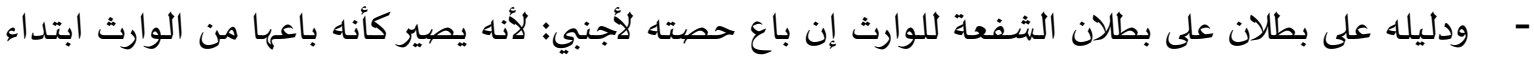

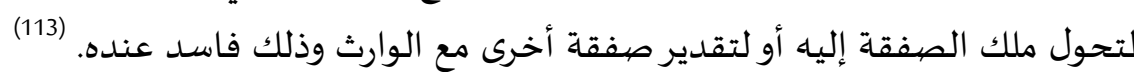

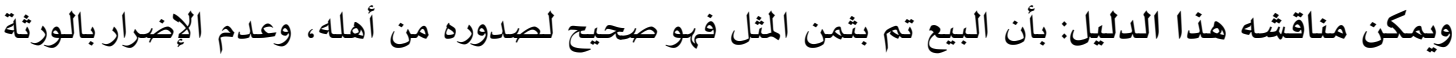
فلا مانع من وصوله للوارث بثمن المثل عن طريق الشفعة.

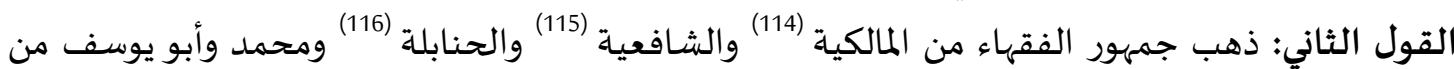
الحنفية (117) إلى أن بيع المريض إن كان بثمن المثل فللشفيع الشفحعةً سواء كان الشفيع والمشتري وارثين أو غيروارثين

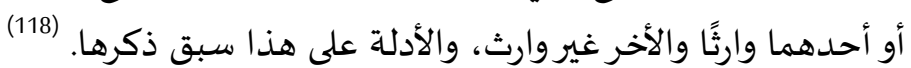
الترجيح: يظهر لي - من خلال ما سبق ذكره من أقوال وأدلة لكل قول ومناقشة ما أمكن مناقشتهـ- رجحان ما ذهب إليه جمهور الفقهاء من ثبوت الشفعة للشريك في حالة بيع المريض لوارث أو غيره إذا تم البيع بثمن المثل؛ لقوة أدلتهم والر د على أدلة المخالفين ولأن البيع تم بثمن المثل ودون إضرار بالورثة.

الفرع الثاني: حكم الشفعة في مبيع المريض بالمحاباة بيع المريض لحصتاه بالمحاباة لا يخلو من حالات ثلاث:

(109) الصنعاني: سبل السلام 106/2.

(110) الكاساني: بدائع الصنائع 114/5)

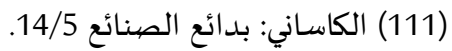
(112) يراجع أدلة القول الثاني المطلب الأول - المبحث الأول.

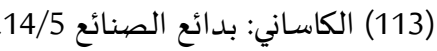

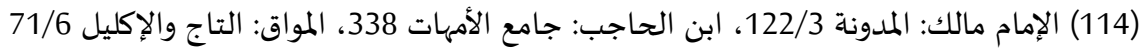

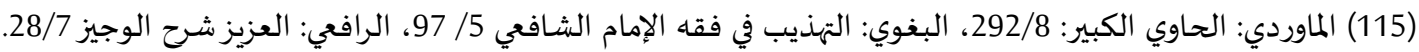

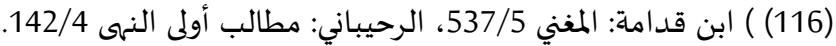
(118) يراجع أدلة أصحاب القول الثاني في المطلب الأول من المبحث الثاني. 
الحالة الأولى: أن يكون المشتري والشفيع أجنبيان: ذهب الحنفية إلى أن المريض إذا باع دارا بألفين وقيمتها

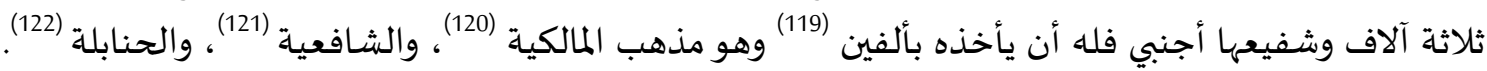
ودليل هذا الاتفاق المعقول:

- - لأنا إنما حاباه بقدر الثلث وذلك صحيح منه في حق الأجنبي فيجب للشفيع فيها الشفعة. (123)

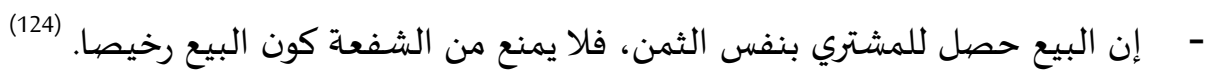

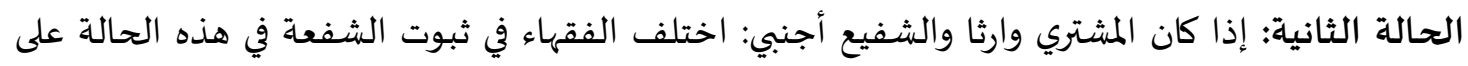
القول الأول: ذهب الإمام أبو حنيفة (125) والشافعية (126)، والحنابلة في قول (127) إلى عدم ثبوت الشفعة

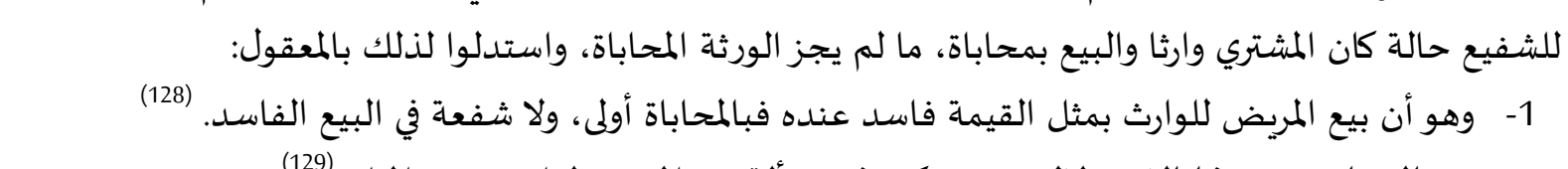

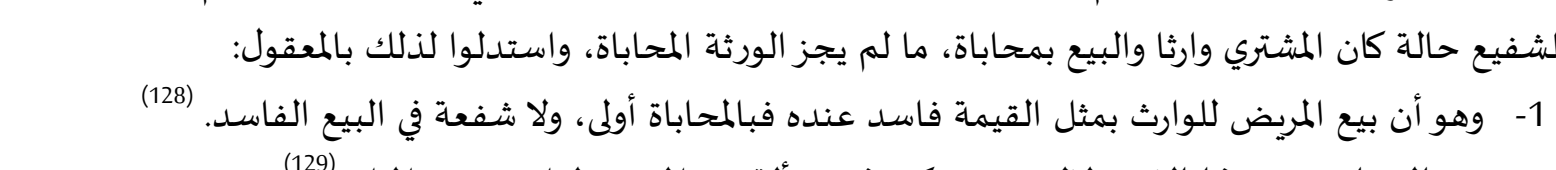

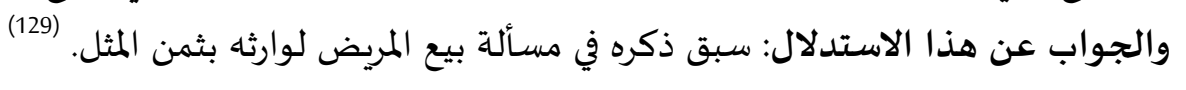

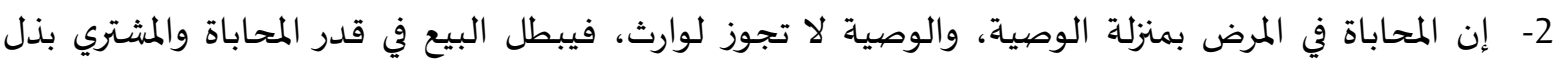
الثمن في كل المبيع، فلم يصح في بعضيه. 130 ويمكن الرد على هذا الدليل: بأن تصحيح البيع ممكن بأن يدفع المشتري قيمة المحاباة للورثة، وبذلك

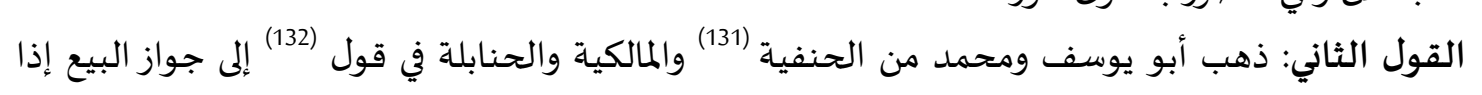
تنتفي علة البطلان وهي الضرر بحقوق الورثة.

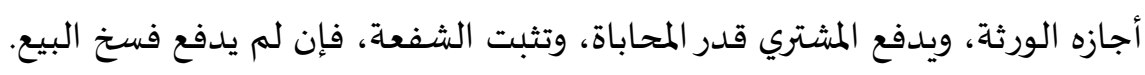

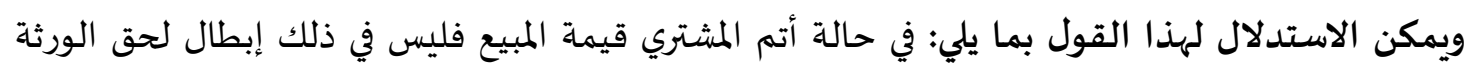

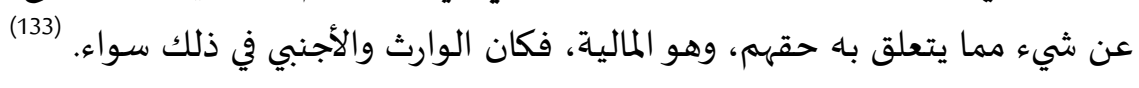

(119) الشيباني: الأصل 270/9، السرخسي: المبسوط 152/14،

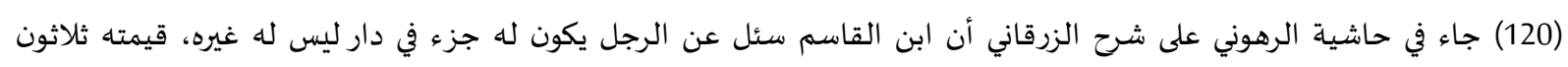

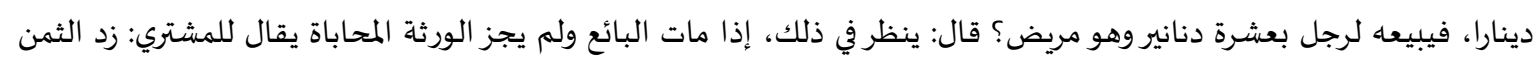

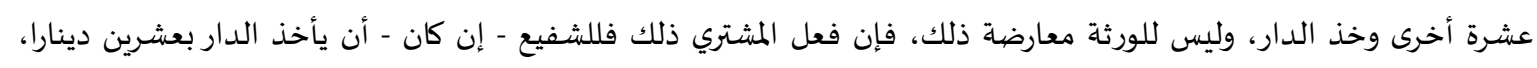

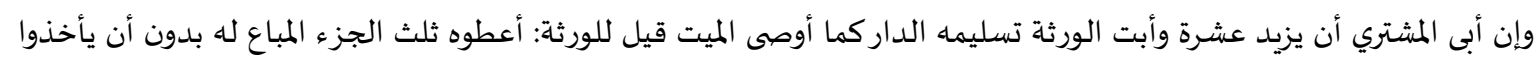

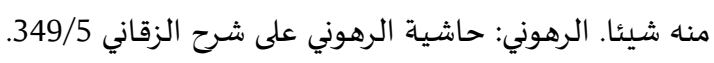

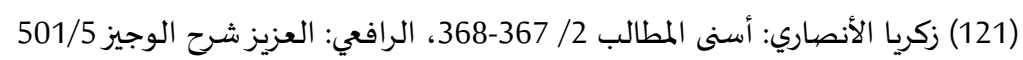
238/5: (122) المغني. (123) السرخسي: 152/14، البلخي: الفتاوى الهندية 196/5) المفني: . 338 المغني

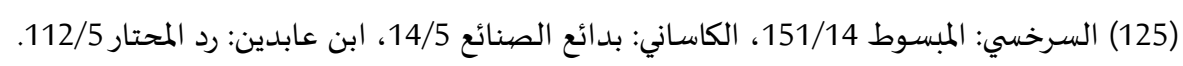

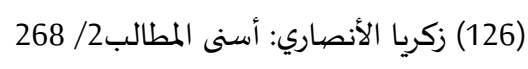

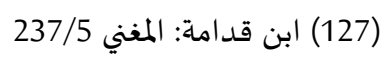

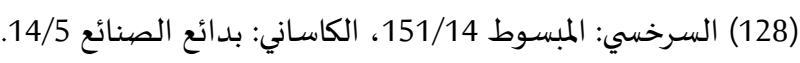

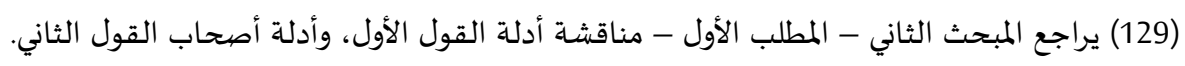
(130) ابن قدامة: المغني 237/5. 14/5 الكاساني: بدائع الصنائع

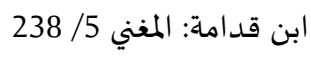


الترجيح: بعد ذكر أقوال الفقهاء لحالة بيع المريض لوارثه بالمحاباة مع كون الشفيع أجنبي، وذكر حجة كل

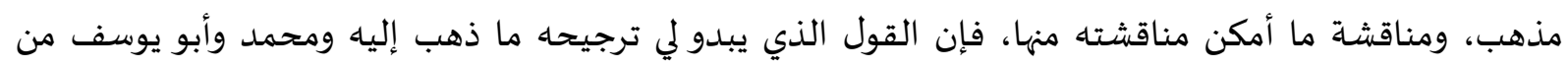

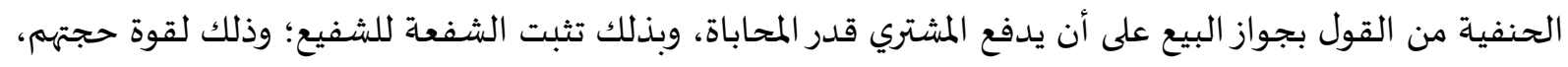
وضعف أدلة المخالفين، والرد عليها.

الحالة الثالثة: إذا كان الشفيع وارثا والمشتري أجنبيا: اختلف الفقهاء في إثبات الشفعاة أو نفيها إلى قولين

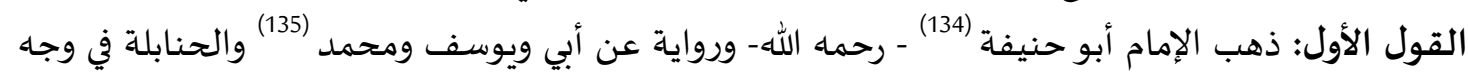

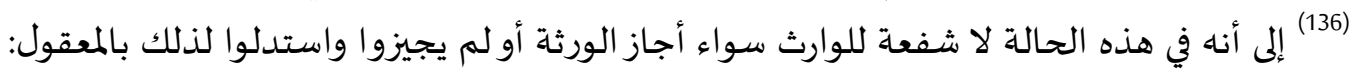

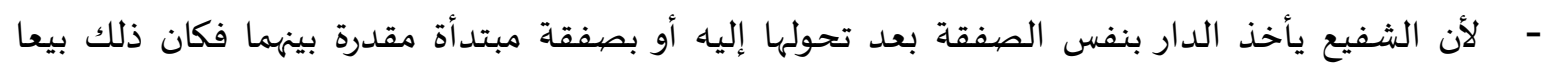

$$
\text { للوارث بالمحاباة. }
$$

ويجاب عن هذا الدليل: بأن المحاباة وقعت لغير الوارث، فلم يمنع منها تمكن الوارث من أخذها، كما لو وهب غريم وارثه مالا، فأخذه الوارث. (137) القول الثاني: ذهب المالكية (138) والحنابلة في وجه (139)، وأبو سف والخف ومحمد (140) من الحنفية إلى أن البيع

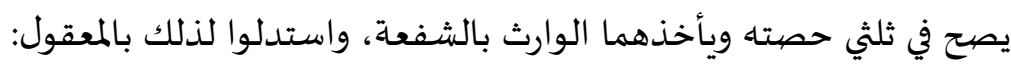

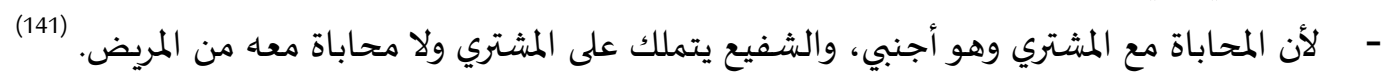

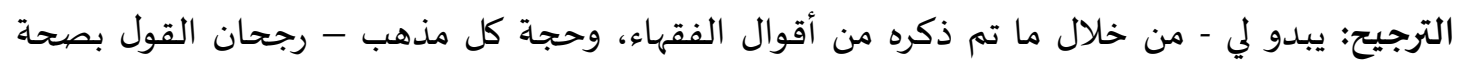

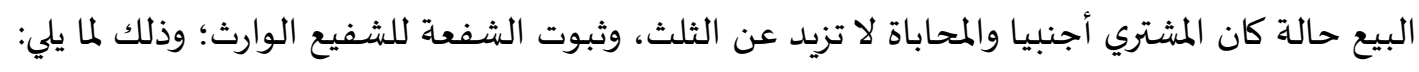

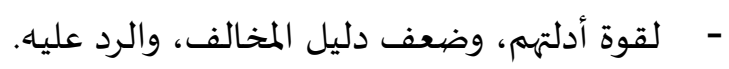

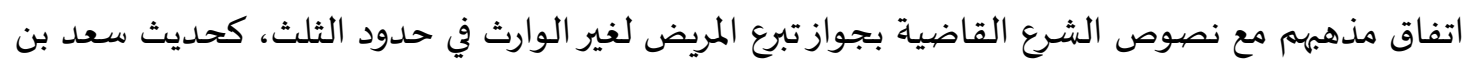
أبي وقاص السابق ذكره. (142) 
المبحث الخامس: الأثر المترتب على مضي زمن الخيار (143) لعذر الإصهابة بالوباء تمهيد: قد يشتري الشخص أو يبيع سلعة على أن له الخيار مدة معلومة يستطيع خلال هذه المدارة المداء أن يقرر

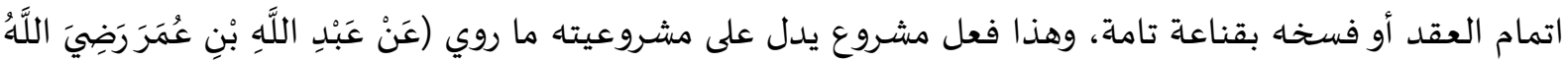

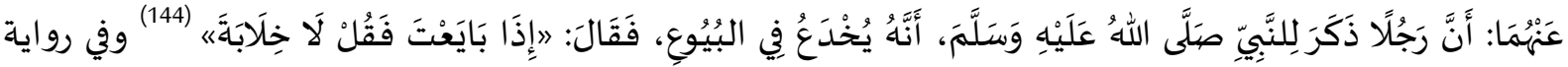

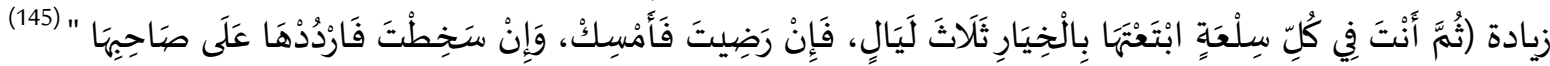

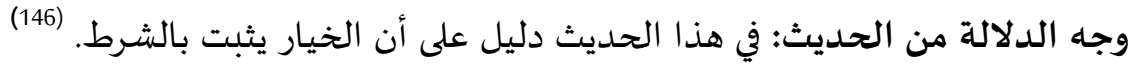

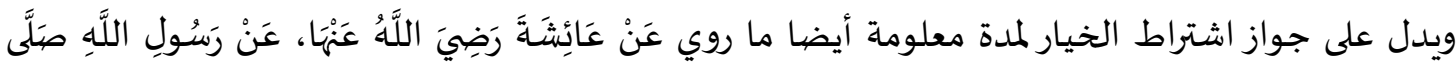

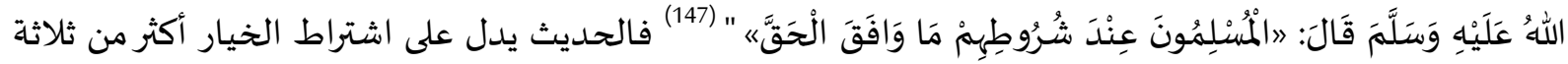

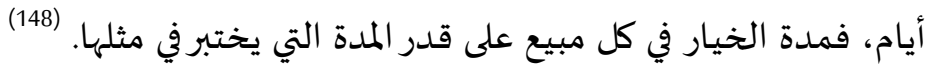

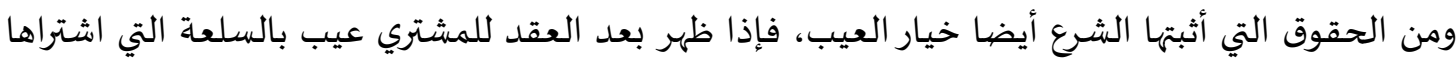

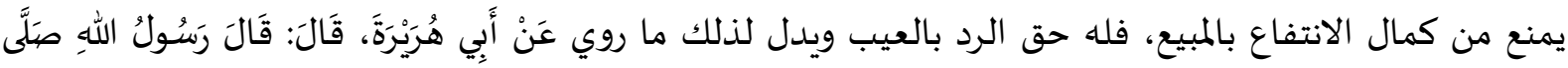

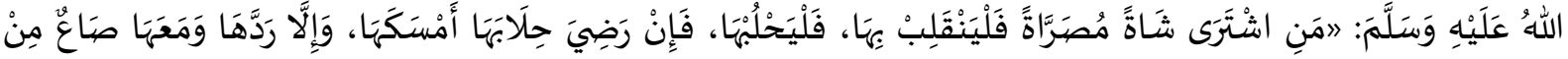
تَمْمرِ

وجه الدلالة من الحديث: في الحديث دليل على ثبوت الخيار في البيوع المشتملة على تدليس. (150)

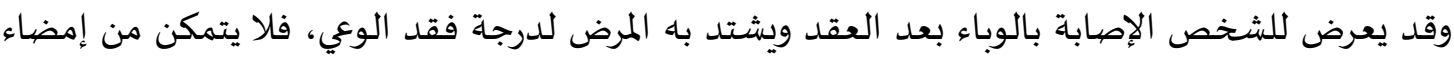
البيع أو فسخح. فالكلام في هذه المبحث يتفرع إلى فرعين:

(143) الخيار لغة: الاسم من الاختيار، وهو طلب خير الأمرين: إما إمضاء البيع أو فسخه. ابن منظور: لسان العرب 4/ 267، فصل الخاء المعجمة، مادة خار.

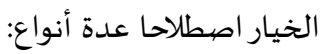
خيار الشرط: أن يشترط أحد المتعاقدين الخيار ثلاثة أيام أو أقل. خيار الرؤية: هو أن يشتري ما لم يره، ويردّه بخياره.

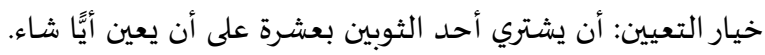

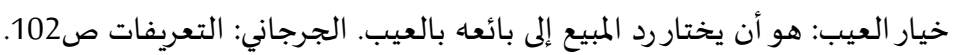

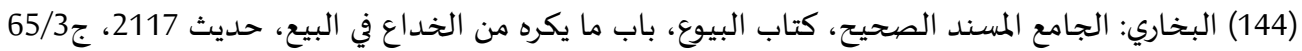

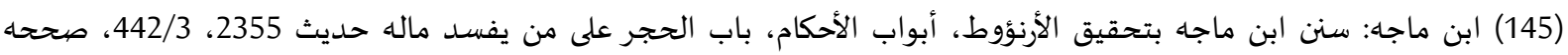

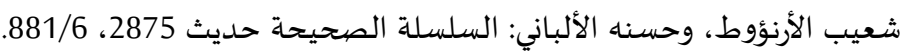
1915/5 الملال علي القاري: مرقاة المفاتيح.

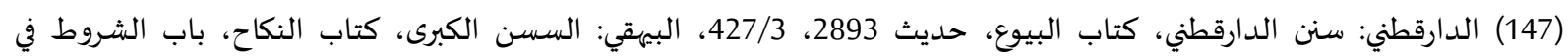

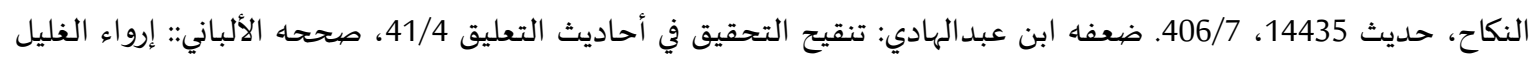


الفرع الأول: فقدان الوعي للمصياب بالوباء وأثره على خيار الشرط لم ينص الفقهاء على هذه الحالة ولكن يمكن تخريجها على مسألة الجنون أو الإغماء بجامع فقدان الأهلية

وقد اختلف الفقهاء في هذه المسألة على قولين:

القول الأول: ذهب الحنفية (151) إلى أنه إذا أفاق في مدة الفئ الخيار فئ فخياره باق؛ لإمكان الفسخ والإجازة، فإن لم

يفق حتى مضت مدة الخيارسقط خياره. واستدلوا لما ذهبوا إليه بالمعقول:

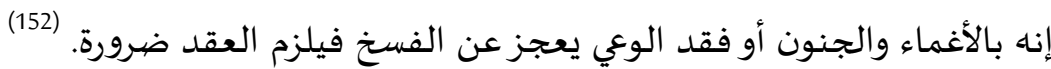

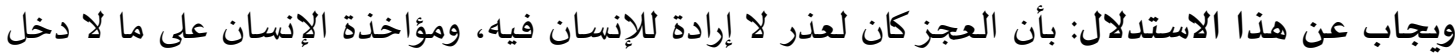

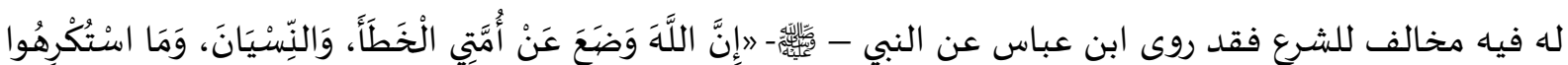

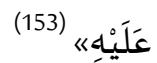
وجه الدلالة من الحديث: في الحديث دليل عدم مؤاخذة الإنسان بما نسى أو استكره عليه، وفقدان الوعي بالإغماء أو غيره يشبه ذلك.

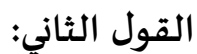
ذهب المالكية (154) إلى أنه إن أغمي على من له الخيار قبل اختياره فإنه تنتظر إفاقته لينظر لنفساه بعد إفاقته ولو تأخرت عن أيام الخيار، وإن طال فينظر السلطان، فإن رأى ضررا فسخ البيع، وليس له أن يمضيه، والطول ما أدى إلى ضرر الآخر، فإن لم يفسخ حتى أفاق بعده فهو باق على خياره.

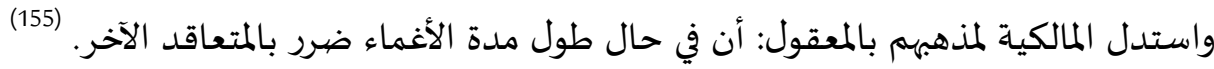
والشرع نهي عن الضرر ففي الحديث (لا ضرر ولا ضرار). (156)

ويمكن مناقشة مذهب المالكية بما يلي: - إن الانتظار حتى افاقته بعد انتهاء مدة الخيار قد يضر بالطرف الآخر حتى وإن كان لفترة قصيرة خاصية وأنها غير معلومة. القول الثالث: ذهب الشافعية (157) والحنابلة (158) إلى أنه لا ينقطع خياره، ويقوم وليه أو الحاكم مقامه،

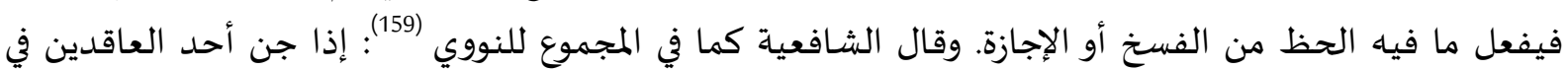

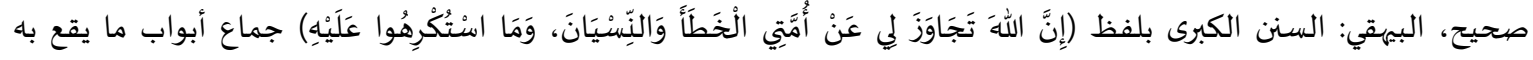

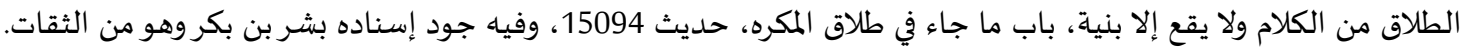

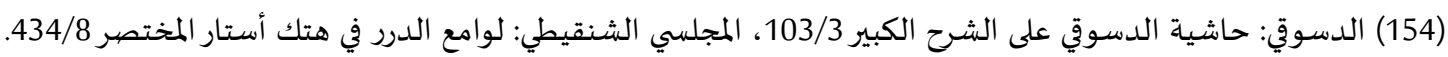
(155) (156) نفس المراجع السابقة. (156) سبق تخريجه في المبحث الثاني- المطلب الأول.

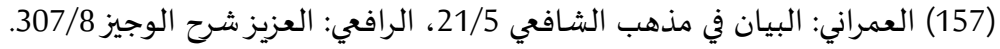

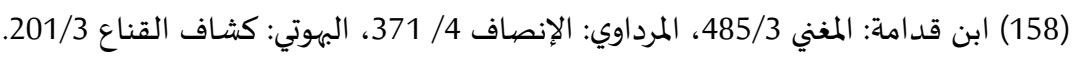

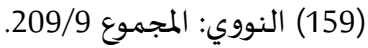


مدة الخياروأقام القاضي قيما يقوم مقامه في الخيار، ففسخ القيم أو أجاز، فأفاق العاقد وادعى أن الغبطة خلاف

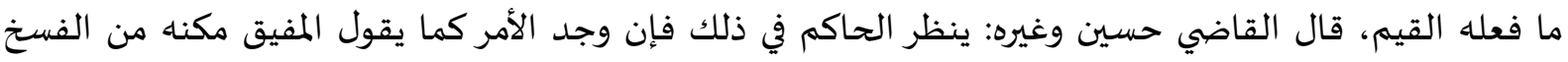
والإجازة، ونقض فعل القيم، وإن لم يكن ما ادعاه المفيق ظاهرا، فالقول قول القيم مع يمينه؛ لأنه أمين فيما فعله فئ،

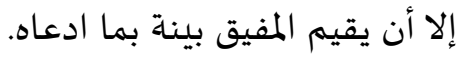

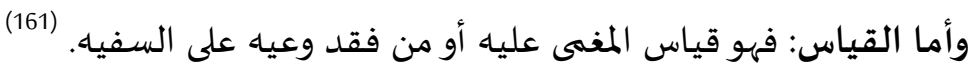

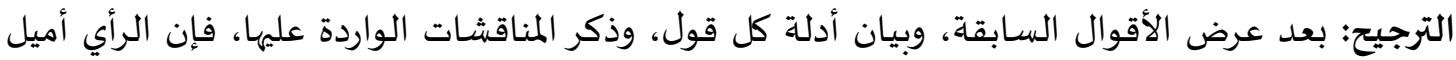
إلى ترجيحه هو ما ذهب إليه الشافعية والحنابلة من القول بعدم سقوط خيار الشرط عن المريض بسبب فقده لوعيا، ويقوم وليه أو الحاكم مقامه، فيفعل ما فيه الحظ من الفسخ أو الإجازة، وذلك لما ما يلي:

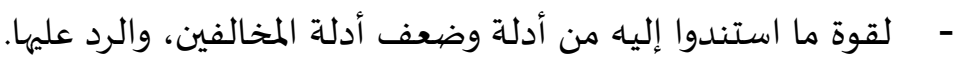

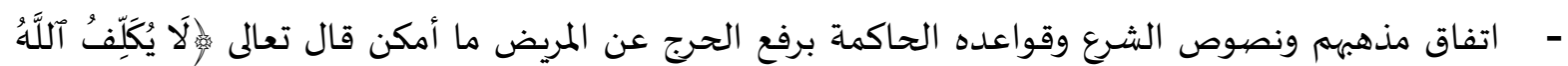

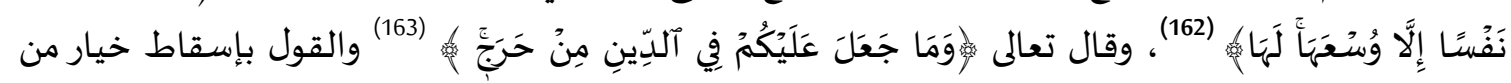

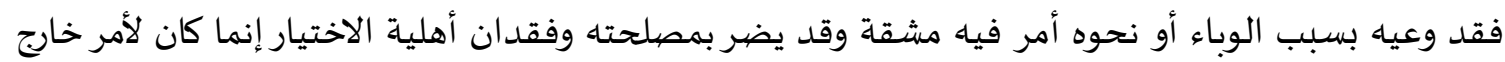
عن إرادته، وهناك من السبل ما يتحقق به مصلحته وهو إنابة القاضي لقيم يختار ما فيه مصلحته وهذا لا لا يضر بمصلحة الطرف الآخر، فوجب اللجوء إليه.

الفرع الثاني: فقدان الوعي للمصاب بالوباء وأثره على خيار العيب قد يكتشف المشتري في المبيع عيبا مؤثرا بعد العقد ولا يتمكن من الرد على الفور فهل علمهاه بالعيب بعد

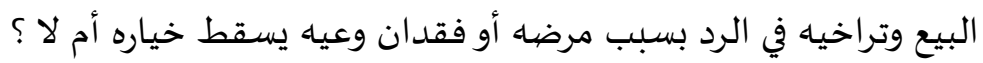

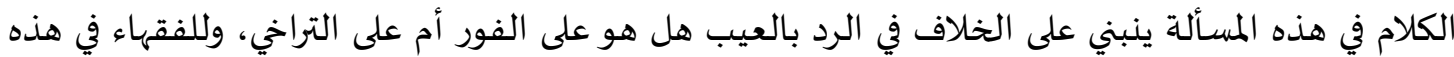

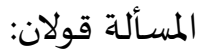
القول الأول: ذهب الحنفية في المعتمد (164) والحنابلة في الصحيح من مذهبهم (165) إلى أن حق الخيار في الرد بالعيب على التراخي وأنه لا يتوقت بزمن معين إلى أن يوجد ما يسقطه مما يدل على الرضا، واستدلوا لمذههبهم بالمعقول: بالعيب: 1- إنه خيار لدفع ضرر متحقق فكان على التراخي، كالقصاص، ولا نسلم دلالة الإمساك على الرضا به. (166)

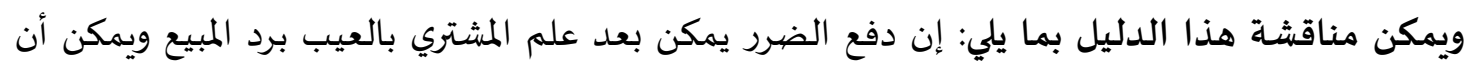

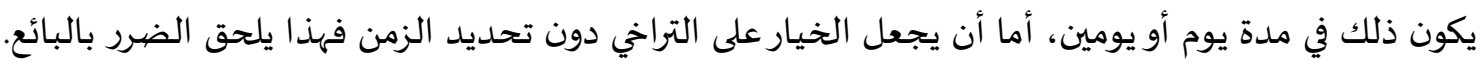

$$
\begin{aligned}
& \text { (160) الرافعي: العزيزشرح الوجيز 307/8. } \\
& \text { (161) الهوتي: كشاف القناع البرافي العزن الوجيز } \\
& \text { (162) سورة البقرة من آية (286) العولي: } \\
& \text { (163) سورة الحج من آية (78) سنوة البة (162) }
\end{aligned}
$$

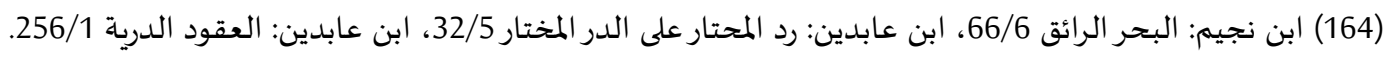

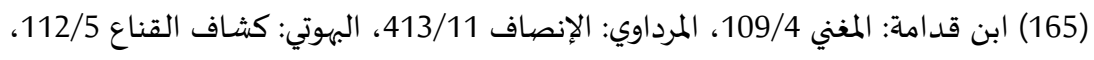

(166) ابن قدامة: المفني 109/4، كشاف المفناف القناع 112/5. 
والقياس على القصاص قياس مع الفارق؛ إذا لا ضرر في تأخير القصاص للتخيير بينه وبين الدياة، وها هنا الضرر متحقق على الطرف الآخر.

وإمساك المبيع المعيب مع علمه دلالة الرضا بالعيب، والرضا بالعيب يمنع الرجوع بالنقصان كما يمنع الرد.

القول الثاني: ذهب المالكية (168) والشافعية (169) والإمام أحمد في رواية (170) إلى أن حق الخيار في الرد

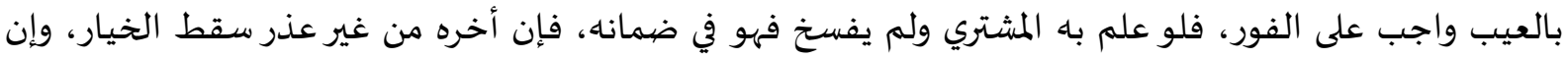

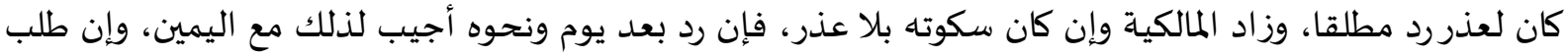
الرد قبل مضي يوم أجيب لذلك من غير يمين، وإن طلب الرد بعد أكثر من يومين فلا يجاب، ولو مع اليمين.

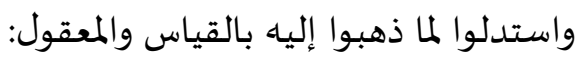

أولا من القياس: القياس على حق الشفعة لورود النص فيها وكلاهما خيار ثبت بالشرع لا للتروي، بل لدفع

الضيرر. (171)

ثانيا من المعقول: أن الأصل في البيع اللزوم فإن أمكنه الرد وقصر لزمه حكمه، وخيار العيب ثبت بالسنة والاتفاق، والقدر المحقق من الإجماع ثبوته على الفور، والزائد على ذلك لم يدل عليه إجماع ولا نص، فيكون على

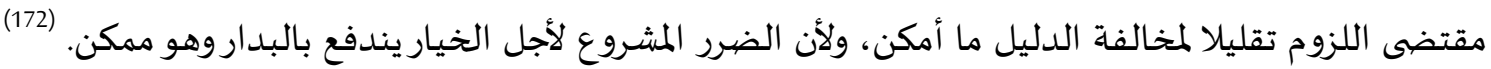

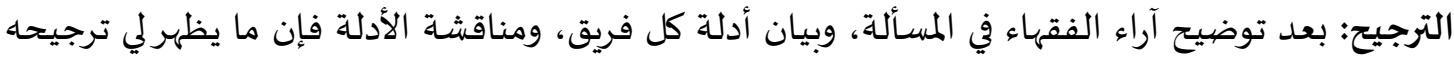

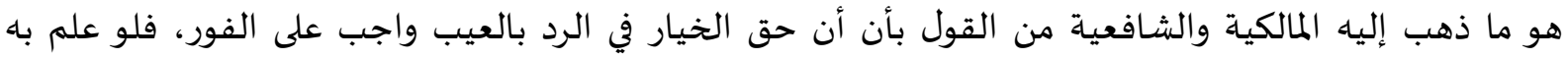

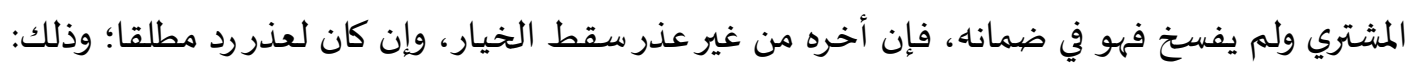

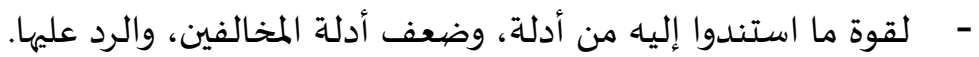

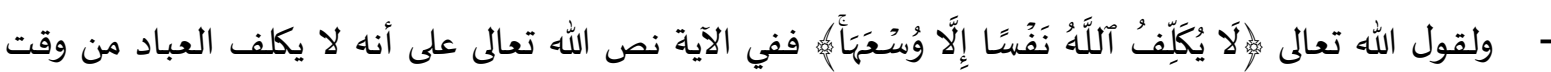

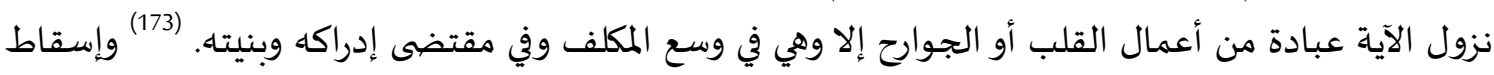

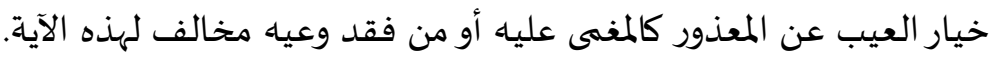

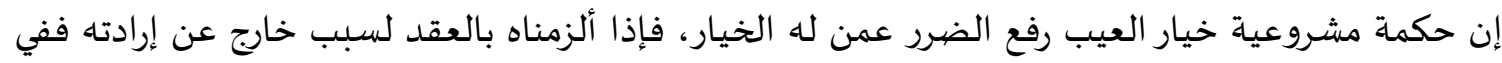
هذه مخالفة لما شرع خيار العيب من أجلها.

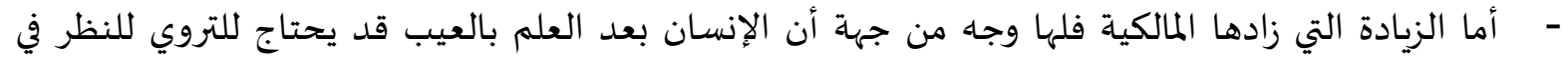

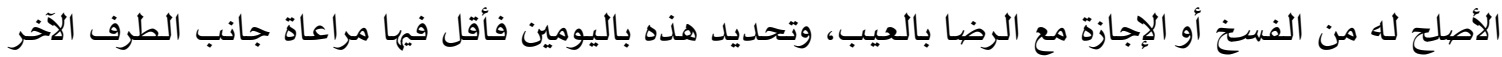
وعدم الإضرار باء.

(167) الكاساني: بدائع الصنائع 289/5، القاضي عبد الوهاب: التلقين في الفقه المالكي 155/2

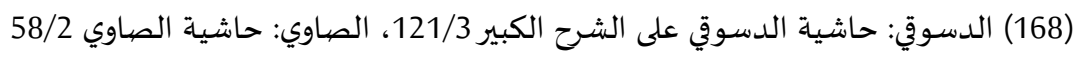

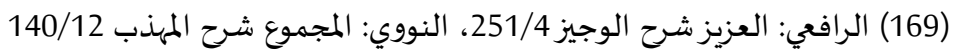
(170) (171) ابن قدامة: المغني. (171) الرافعي: العزيزشح الوجيز 251/4، النووي: المجموع شرح المهذب 170/170/12. (172) نفس المرجعين السابقين. (173) القرطبي: تفسير القرطبي 429/3. 
تم - بعون الله وتوفيقه - الانتهاء من هذا البحث عن الأحكام الفقهية المتعلقة بوباء كورونا في عقود المعاوضات المالية (عقد البيع أنموذجا)

وهذه بإيجاز أهم النتائج التي توصلت إنودجا إليها من خلال هذا البحث:

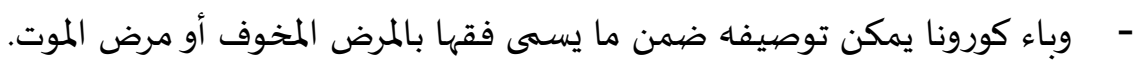

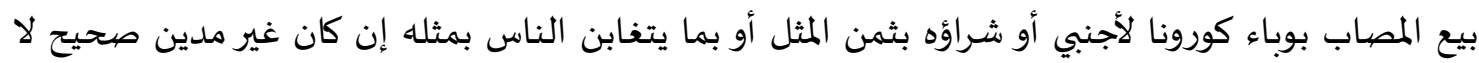

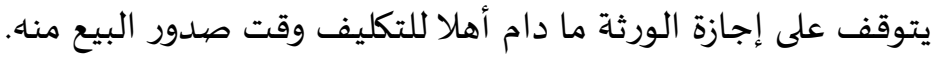

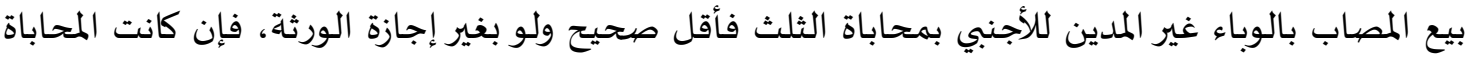

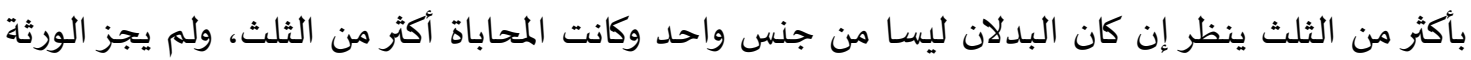

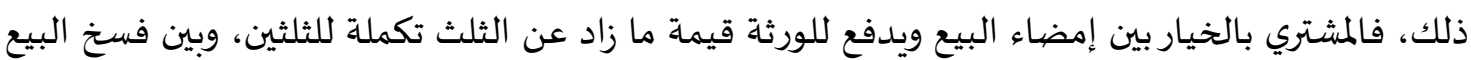
ورد المبيع للورثة، وإذا كان البدلان من جنس واحد من الأموال الربوية، فليس من حق الورئة الورئة إجبار المشتري

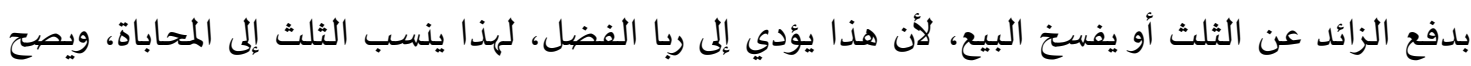

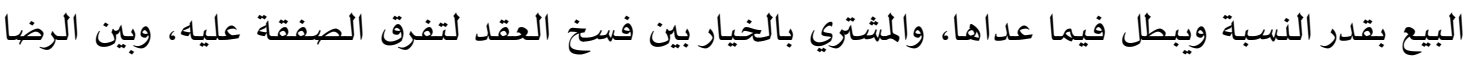
بالبيع في القدر الباقي. المصاب بالوباء إذا باع شيئا من ماله لأجنبي بثمن المثل وكان عليه دين مستغرق لجميع تركته فإن البيع صحيح، ولا يحق للدائنين الاعتراض عليه. محاباة المصاب بالوباء المدين بدين يستغرق جميع ماله في البيع أو الشراء لا تنفذ مطلقا قليلة كانت أم كثيرة

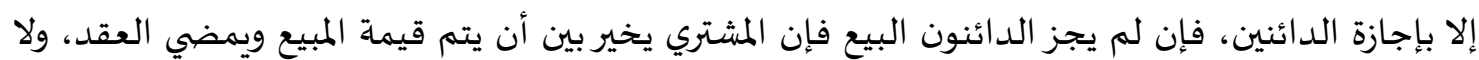

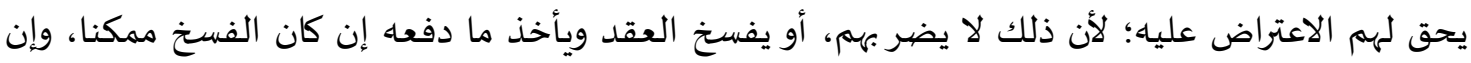

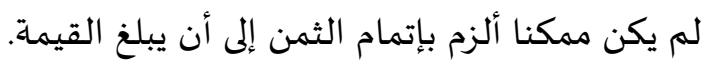

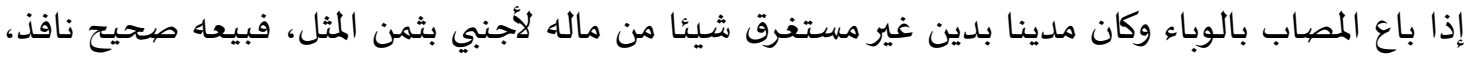

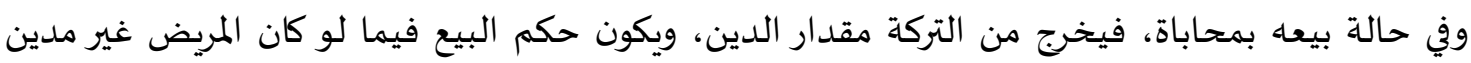
أصلا بالنسبة للباقي. بيع المصاب بالوباء لوارثه بثمن المثل صحيح نافذ دون توقف على إجازة أحد الورثة؛ لأن البيع صهدر من أهله، ولأنه ليس في تصرفه إبطال حق الورثة عن شيء مما تعلق حقهم به وهو المالية، والوارث لواث والأجنبي في

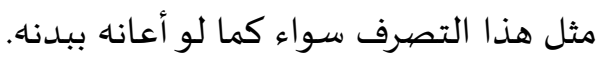

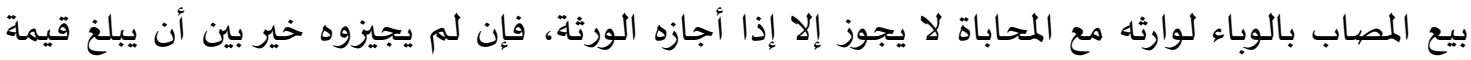
المبيع وبين فسخ البيع وأخذ ما دفعها. المصاب بوباء كورونا إذا كان مدينا بدين يستغرق جميع ماله، وباع شيئا من ماله لوارثيه بثمن المثل فبيعها

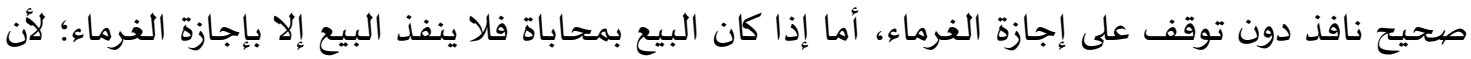

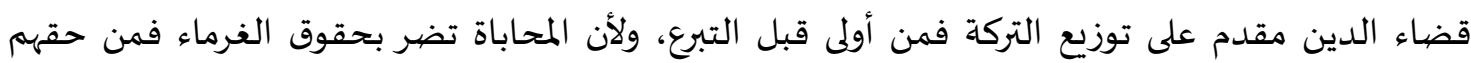
الاعتراض على ذلك. ثبوت الشفعة للشريك في حالة بيع المريض لوارث أو غيره إذا تم البيع بثمن المثل.

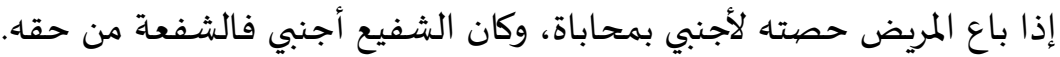


- - - إذا باع المريض لوارثه بالمحاباة وكان الشفيع أجنبيا فالبيع جائز على أن يدفع المشتري قدر المحاباة، وبذلك

تثبت الشفعة للشفيع.

- - محة البيع حالة كان المشتري أجنبيا والمحاباة لا تزيد عن الثلث، وثبوت الشفعة للشفيع الوارث. - عدم سقوط خيار الشرط عن المريض بسبب فقده لوعياه لإغماء أو نحوه، ويقوم وليه أو الحاكم مقامهاه، فيفعل ما فيه الحظ من الفسخ أو الإجازة.

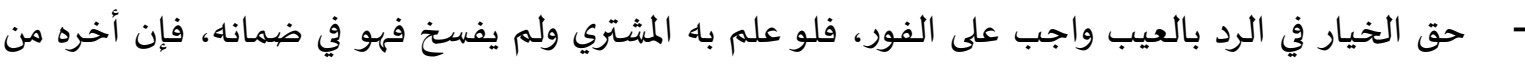
غير عذر سقط الخيار، وإن كان لعذر ردد مطلقا. وختاما: فما كان من صواب فمن الله - له الحمد أولا وآخرا - وما كان من خطأ أو سهو أو أو تقصير أو نسيان فمني ومن الشيطان والله ورسوله منه براء، واستغفر الله عما كان من من زلل.

$$
\text { التوصيات والمقترحات. }
$$

استنادا لنتائج البحث يوصي الباحث ويقترح ما يلي: 1. ضرورة نشر الوعي بضرورة التحلي بالصبر والرضا بالقضاء عند نزول بالبلاء والاستسلام لأوامر الله - عز وجل ليال

$$
\text { - وتحري عدم الاضرار بالآخرين. }
$$

2. نشر الوعي المجتمعي بالأحكام الشرعية المتعلقة بالأوبئة والتعامل الشرعي معها من خلال وسائل الإعلام

المختلفة.

3. اهتمام الباحثين بمزيد من الأبحاث المتعلقة بأحكام الأوبئة.

شكروتقدير:

يتقدم الباحث بجزيل الشكروالتقدير لجامعة الملك خالد على الدعم الفني والإداري لهذا البحث.

قائمة المصيادر والمراجع:

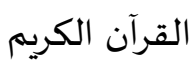

- ابن الحاجب: عثمان بن عمر بن أبي بكر بن يونس، الكردي المالكي) المتوفى: 646 هـ: جامع الأمهات، المحقق: أبو

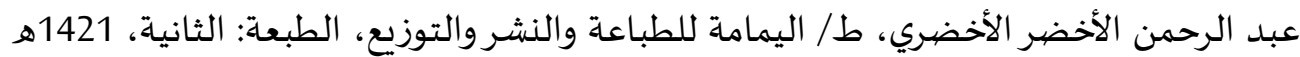

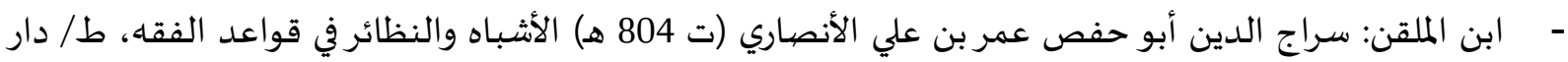
ابن القيم للنشروالتوزيع، الرياض - المملكة العربية السعودية.

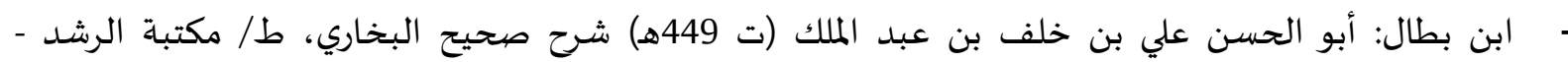

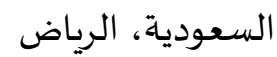

ابن حجر العسقلاني: أبو الفضل أحمد بن علي بن محمد بن أحمد (المتوفى: 852هـ) بلوغ المرام من أدلة الأحكام،

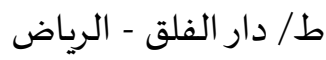
ابن حجر العسقلاني: أبو الفضل أحمد بن علي بن محمد بن أحمد التلخيص الحبير (ت 852هـ) طل دار الكتب العلمية. - ابن رشد الجد: أبو الوليد محمد بن أحمد (ت 520هـ) البيان والتحصيل، ط/ دار الغرب الإسلامي، بيروت لبنان. 
- ابن شاس: أبو محمد جلال الدين عبد الله بن نجم (ت 616هـ) عقد الجواهر الثمينة في مذهب عالم المدينة، ط/ دار الغرب الإسلامي، بيروت - لبنان.

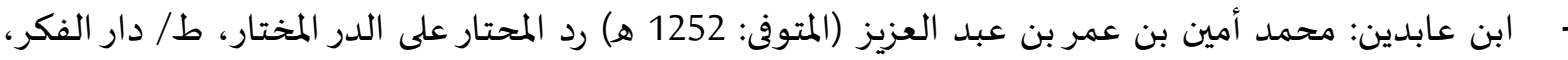

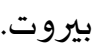
ابن عابدين: محمد أمين بن عمر بن عبد العزيز (ت 1252هـ) العقود الدرية في تنقيح الفتاوى الحامدية، طا دار المعرفة. ابن عبد البر: أبو عمر يوسف بن عبد الله بن محمد (المتوفى: 463ه) المحقق: محمد محمد أحيد ولد ماديك

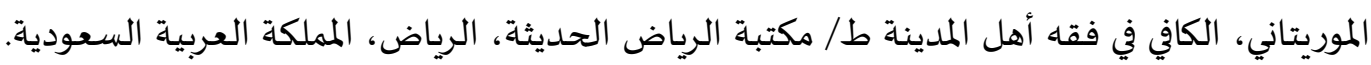

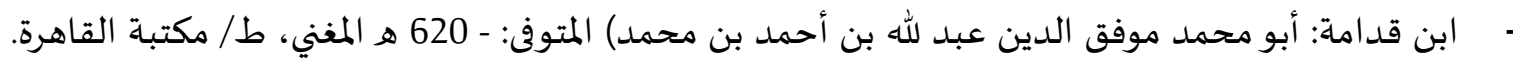

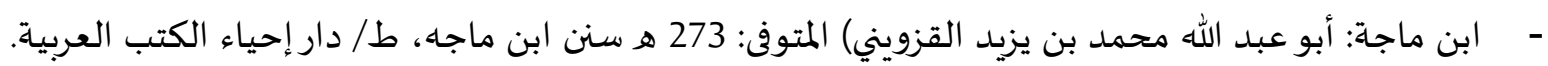

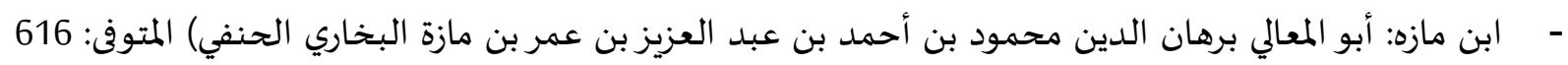

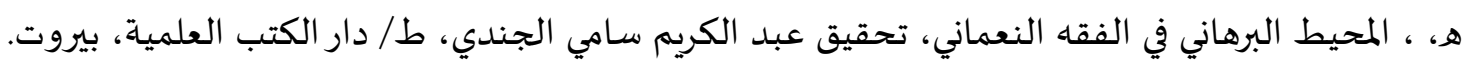

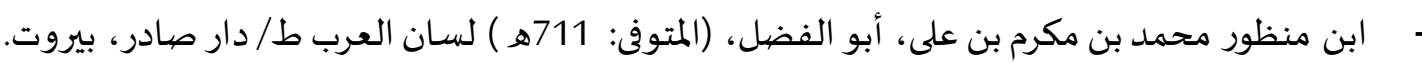

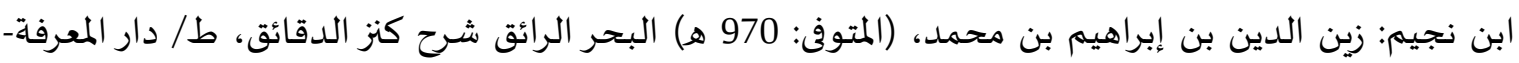

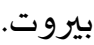
أبو زيد القيرواني: أبو محمد عبد الله بن عبد الرحمن النفزي (ت 386هـ) النوادروالزيادات على مَا في المدَوَّنة من

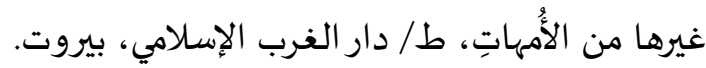

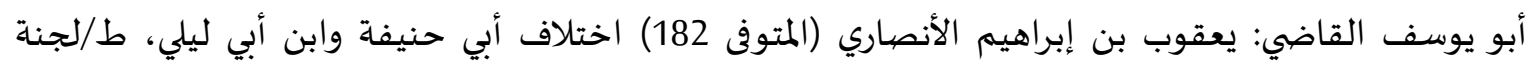

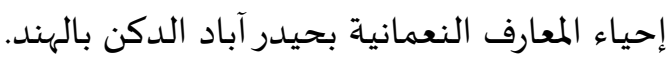
الألباني: أبو عبد الرحمن محمد ناصر الدين (ت 1420هـ) صحيح الجامع الصغير وزياداته، طا / المكتب الإسلامي.

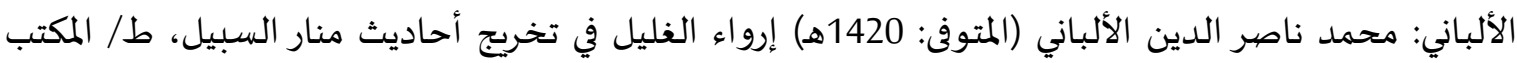

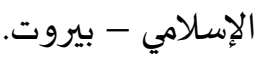

الإمام مالك: مالك بن أنس بن مالك بن عامر الأصبحي المدني (ت 179هـ) المدونة، طالت د دار الكتب العلمية.

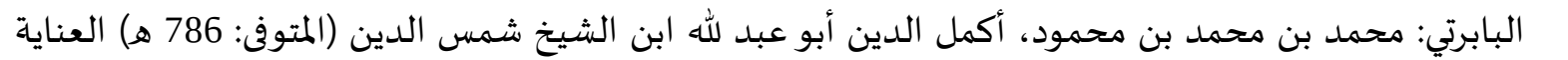

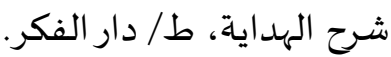
الباجي: أبو الوليد سليمان بن خلف بن سعد بن أيوب) المتوفى: 474 هـ المنتقى شرح الموطأ، طار دار الكتاب الإسلامي، القاهرة. - البخاري: محمد بن إسماعيل أبو عبد الله (ت 256هـ) الجامع المسند الصحيح المختصر من أمور رسول لله صلى

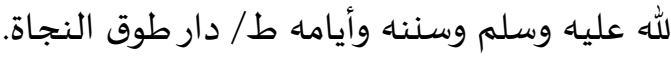
- البركتي: محمد عميم الإحسان (المتوفى 1395ه) التعريفات الفقهية، طاه دار الكتب العلمية، الطبعة: الأولى،

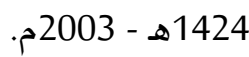
برهان الدين بن مفلح: إبراهيم بن محمد بن عبد الله بن محمد) (المتوفى: 884 هـ) المبدع في شرح المقنع، طار دار الكتب العلمية، بيروت لبنان. 
- البغوي: أبي محمد الحسين بن مسعود بن محمد بن الفراء (المتوفي سنة 516 هـ) التهذيب في فقه الإمام الشافعي، ط/ دار الكتب العلمية. - البكري الدمياطي: أبو بكر عثمان بن محمد شطا (ت 1310هـ) إعانة الطالبين على حل ألفاظ فتح المعين، طال دار الفكر للطباعة والنشر والتوريع.

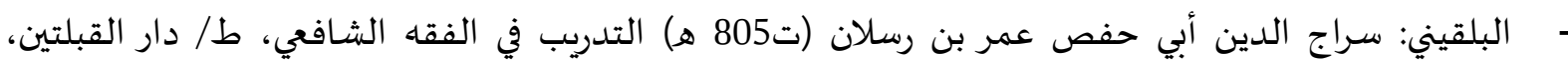
الرياض - المملكة العربية السعودياة. بهاء الدين المقدسي: عبد الرحمن بن إبراهيم بن أحمد (المتوفى 624هـ) العدة شرح العمدة، ط/ دار الحديث، القاهرة.

الههوتي: منصور بن يونس بن صلاح الدين بن حسن بن إدريس (ت: 1050 هـ) كشاف القناع عن متن الإقناع، ط/ دار الكتب العلمية. - ـ البوصيري: أحمد بن أبي بكر بن إسماعيل (840 هـ) تحقيق: محمد المنتقى الكشناوي، مصبياح الزجاجة في زوائد ابن ماجه ط/ دار العربية، بيروت. الترمذي: محمد بن عيسى بن سَوْرة بن موسى بن الضحاك (ت 279هـ) سنن الترمذي، طارشركة مكتبة ومطبعة

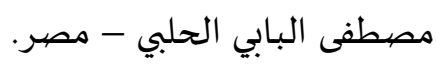

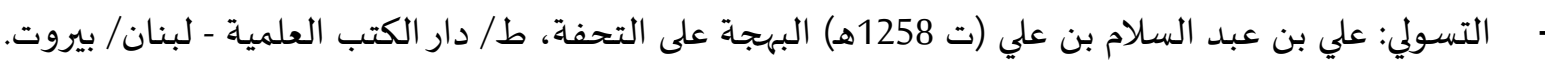

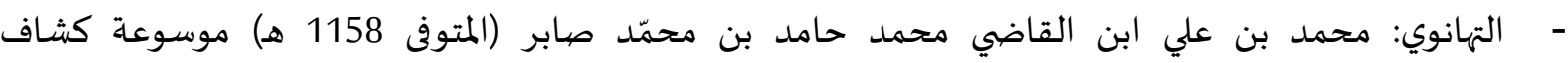

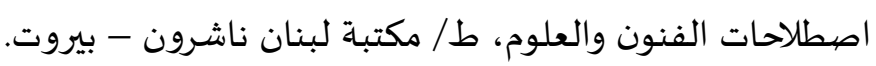

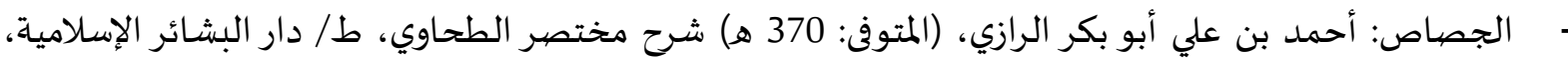

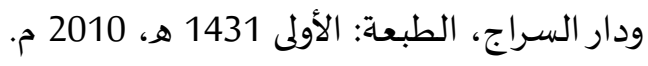

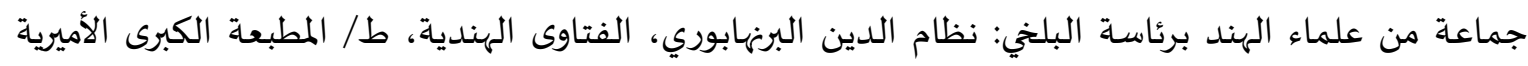
ببولاق مصر. الجمل: سليمان بن عمر بن منصور العجيلي الأزهري (المتوفى1204هـ) حاشية الجمل على شرح المنهج، ط/ دار الفكر. - ـ الحجاوي: موسى بن أحمد بن موسى بن سالم بن عيسى بن سالم (ت 968هـ) الإقناع في فقه الإمام أحمد بن

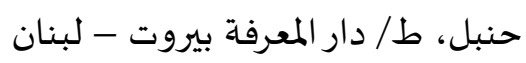
الحداد: أبو بكر بن علي بن محمد (المتوفى 800 هـ) الجوهرة النيرة، طان بـو المطبعة الخيرية.

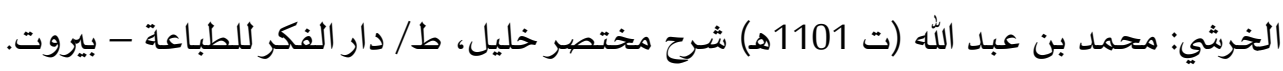

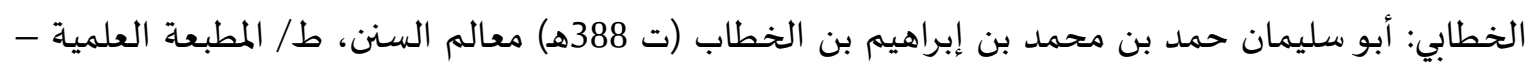
حلب. - ـ خلاف: عبد الوهاب (ت 1375هـ) أحكام الأحوال الشخصية في الشريعة الإسلامية، ط/ مطبعة دار الكتب المصرية بالقاهرة. خليل: خليل بن إسحاق الجندي (المتوفى 776 هـ) مختصر خليل، ط/ دار الحديث- القاهرة، الطبعة: الأولى، 1426هـ/ 2005هـ 
- الدجيلي: سراج الدين أبو عبد اللَّه، الحسين بن يوسف (المتوفي 732) الوجيز في الفقه، مكتبة الرشد ناشرون،

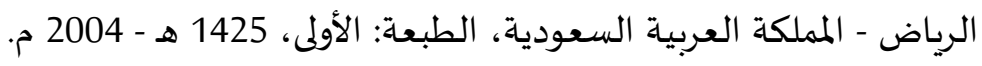

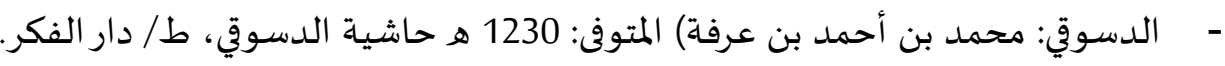

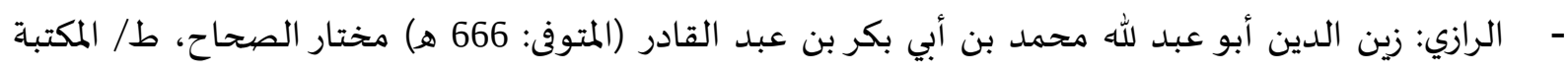
العصرية، بيروت.

$$
\text { - الرافعي: عبد الكريم بن محمد (ت 623هـ) فتح العزيز بشرح الوجيز، ط/ دار الفكر. }
$$

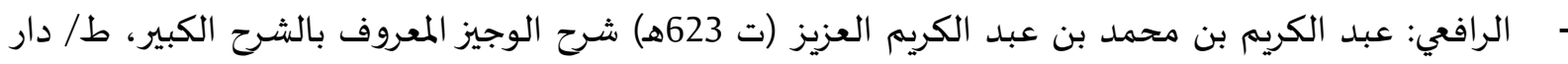
الكتب العلمية، بيروت - لبنان.

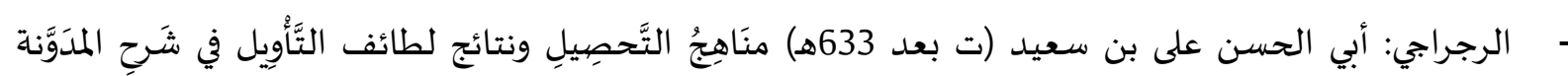

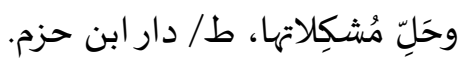

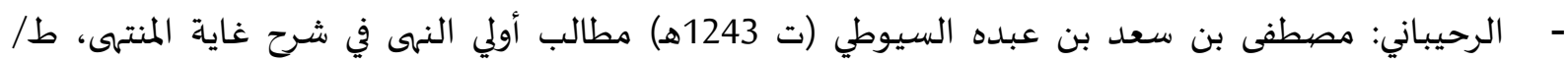
المكتب الإسلامي. - الرصاع: محمد بن قاسم الأنصاري، أبو عبد الله (المتوفى 894هـ) شرح حدود ابن عرفة، طالماهية المكتبة العلمية،

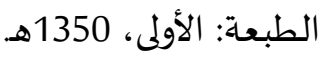
- ـ الرملي: شهاب الدين أبو العباس أحمد بن أحمد بن حمزة (ت 957 هـ) فتح الرحمن بشرح زبد ابن رسلان، طال دار المنهاج، بيروت - لبنان. الرهوني: حاشية الرهوني على شرح الزرقاني لمختصر خليل: محمد بن أحمد بن محممد بن يوسف (ت 1230 هـ)، طا المطبعة الأميرية - ببولاق-مصر. - الزحيلي: وهبة بن مصطفى الفقه الإسلامي وأدلته (ت1436) طادار الفكر - سوريَّة - دمشق.

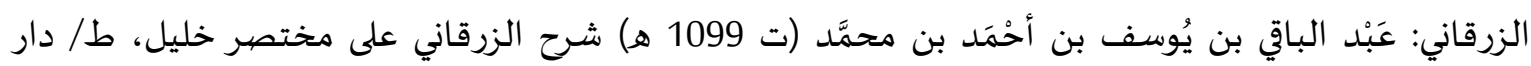
الكتب العلمية، بيروت - لبنان. زكريا الأنصاري: محمد بن زكريا الأنصاري، زين الدين أبو يحيى السنيكي (ت 926هـ) أسنى المطالب في شرح روض المان

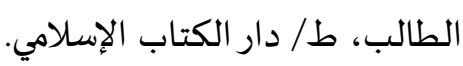

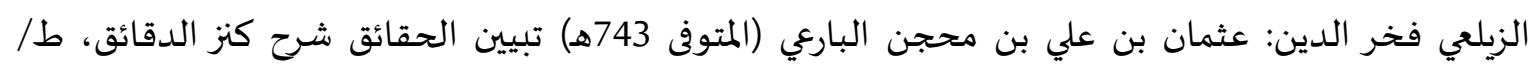
المطبعة الكبرى الأميرية - بولاق، القاهرة. الزيلعي: جمال الدين عبد الله بن يوسف (المتوفى: 762 هـ) نصب الراية في تخريج أحاديث الهداية طاهر دار الحديث. زين الدين المعبري: زين الدين أحمد بن عبد العزيز بن زين الدين بن علي بن أحمد (ت 987 هـ) فتح المعين بشرح

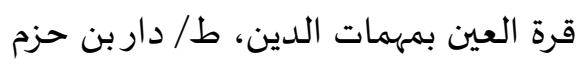

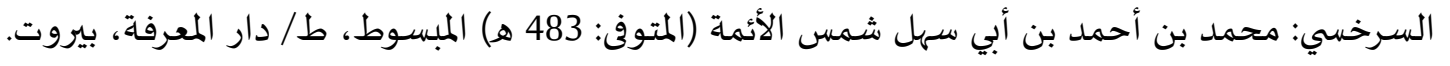

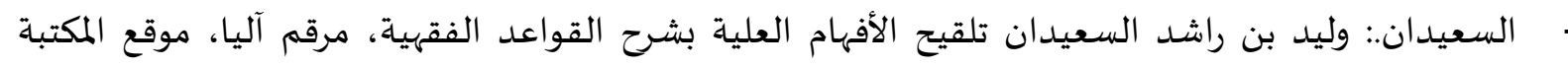

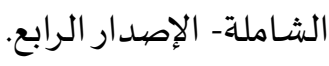

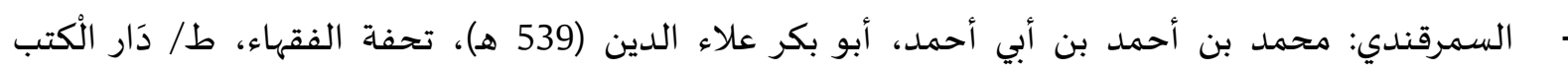
العلمية، بيروت - لبنان. 


$$
\text { - السندي: محمد بن عبد الهادي التتوي (ت 1138هـ) حاشية السندي، دار الجيل - بيروت. }
$$

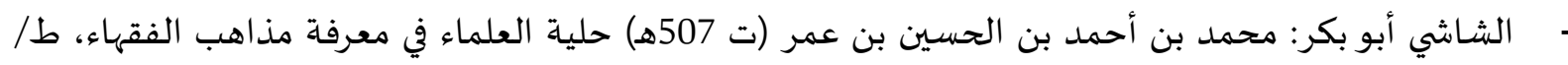

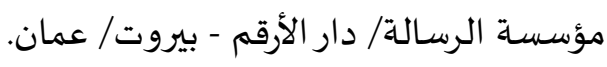

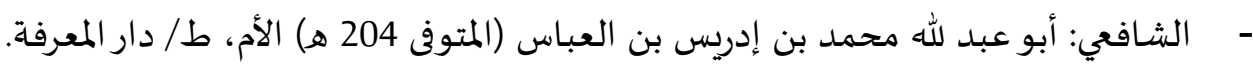
- الشيباني: أبو عبد الله محمد بن الحسن بن فرقد (ت 189هـ) الأصل، طا طا إدارة القرآن والعلوم الإسلامية كراتشي. الشيرازي: أبو اسحاق إبراهيم بن علي بن يوسف الشيرازي (المتوفى: 476 هـ) المهذب في فقه الإمام الشافعي، ط/

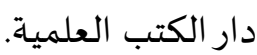

الصنعاني: محممد بن إسماعيل بن صلاح بن محمد الحسني (المتوفى: 1182 هـ)، سبل السلام، طار/ دار الحديث.

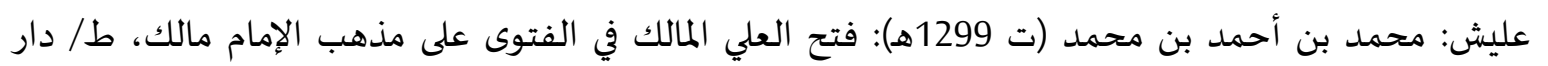
المعرفة.

- الفراهيدي: الخليل بن أحمد الفراهيدي (المتوفى: 170 هـ) العين، ط/ دارومكتبة الهلال.

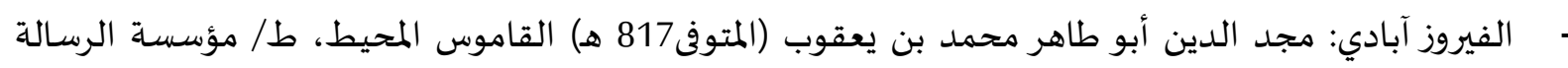
للطباعة والنشر والتوزيع، بيروت - لبنان. القاضي عبد الوهاب: أبو محمد عبد الوهاب بن علي بن نصر (ت ب22هـ)، التلقين في الفقه المالكي، طان دار

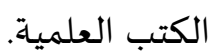
قدري باشا: محمد قدري (المتوفى ت 1306هـ) مرشد الحيران إلى معرفة أحوال الإنسان، ط/ المطبعة الكبرى الأميرية ببولاق. قلعجي: محممد رواس، معجم لغة الفقهاء ط/ دار النفائس..

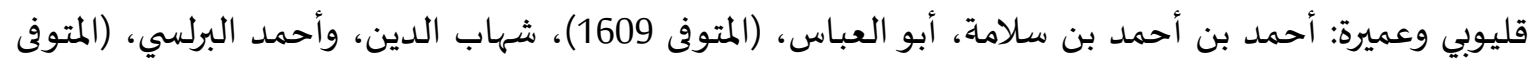

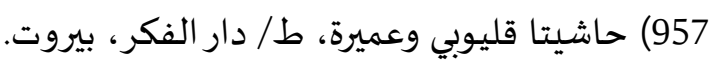

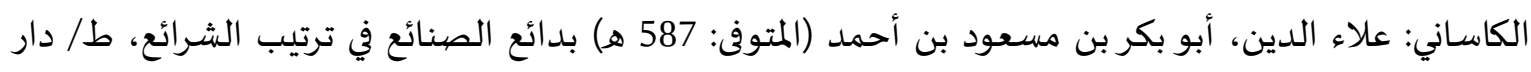
الكتب العلمياة. الكمال بن الهمام: كمال الدين محمد بن عبد الواحد السيواسي (المتوفي 681) فتح القدير على الهداية، ط/ دار الفكر بيروت. لجنة من فقهاء الحنفية: مجلة الأحكام العدلية، ط/ نور محمد، كارخانه تجارتِ كتب، آرام باغ، كراتشي.

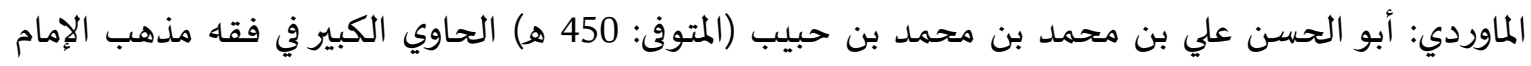

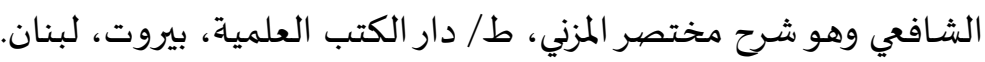

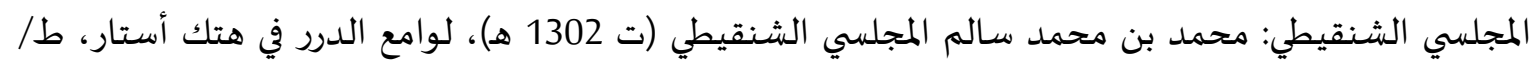
دار الرضوان، نواكشوط- موريتانيا. مختار وآخرون: د أحمد مختار عبد الحميد عمر (المتوفى: 1424هـ) معجم اللغة العربية المعاصرة، طوانعالم الكتب. مرتضى الزبيدي: محمد بن محمد بن محمد بن عبد الرزاق الحسينى (المتوفى 1205ه) تاج العروس من جواهر القاموس، ط/ دار الهداية. 
- المرداوي: علي بن سليمان بن أحمد (المتوفى: 885 ه) الإنصاف في معرفة الراجح من الخلاف، ط/ دار إحياء التراث العربي الطبعة الثانية. - مرعي الكرمي: مرعي بن يوسف بن أبى بكر بن أحمد الكرمى (المتوفى 1033هـ) ما يفعله الأطباء والداعون بدفع

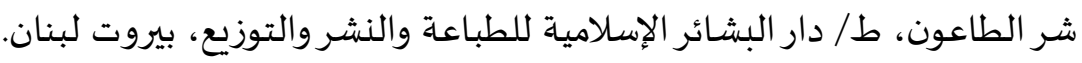

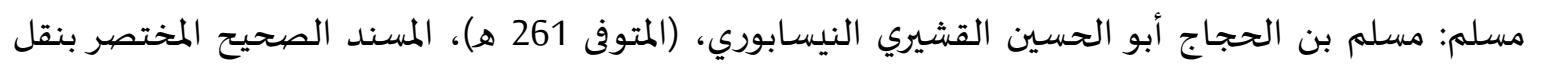

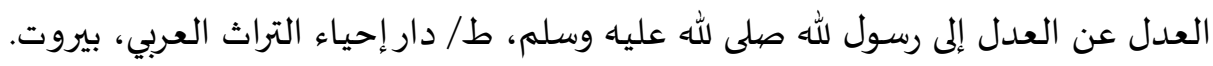

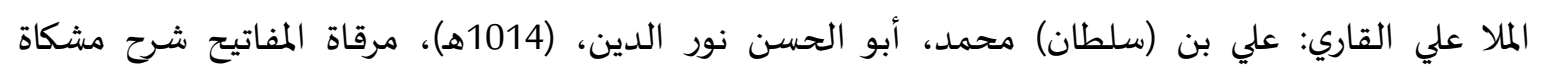
المصابيح، ط/دار الفكر، بيروت - لبنان. منلا خسروا: لمحمد بن فرامرز بن علي (المتوفى: 885 هـ) درر الحكام شرح غرر الأحكام، ط/ دار إحياء الكتب لمكان العربية. المواق: محمد بن يوسف بن أبي القاسم العبدري) المتوفى 867، التاج والإكليل، طا دار الفكر بيروت.

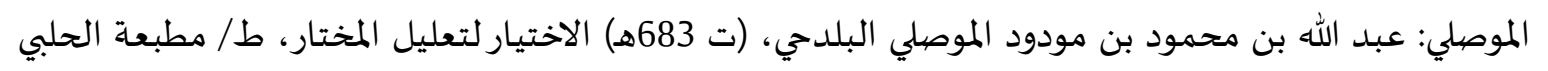
- القاهرة.

- النووي: أبو زكريا محيي الدين يحيى بن شرف (ت 676هـ) تحرير ألفاظ التنبيه، ط/ دار القلم - دمشق.

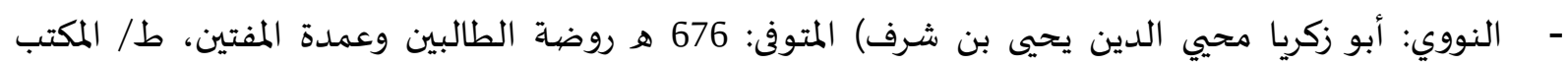
الإسلامي، بيروت. - الهيتهي: أحمد بن محمد بن علي بن حجر (ت974 هـ)، تحفة المحتاج في شرح المنهاج، ط/المكتبة التجارية الكبرى - مصر -

المصيادر الالكترونية:

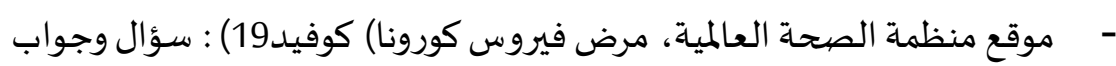
https://www. who. int/ar/emergencies/diseases/novel-coronavirus-2019/advice-for-public/q-acoronaviruses

https://nabd. com/corona- - 